\title{
A PTEN-Regulated Checkpoint Controls Surface Delivery of $\delta$ Opioid Receptors
}

\author{
ĐDaniel J. Shiwarski, ${ }^{1}$ Alycia Tipton, ${ }^{2}$ Melissa D. Giraldo, ${ }^{3}$ 을igitte F. Schmidt, ${ }^{4}$ Michael S. Gold, ${ }^{3}$ \\ Amynah A. Pradhan, ${ }^{2}$ and ${ }^{1}$ Manojkumar A. Puthenveedu ${ }^{1}$ \\ ${ }^{1}$ Department of Biological Sciences, Center for the Neural Basis of Cognition, Carnegie Mellon University, Pittsburgh, Pennsylvania 15213, ${ }^{2}$ Department of \\ Psychiatry, University of Illinois at Chicago, Chicago, Illinois 60612, ${ }^{3}$ Department of Anesthesiology and Pittsburgh Center for Pain Research, University of \\ Pittsburgh School of Medicine, Pittsburgh, Pennsylvania 15213, and ${ }^{4}$ Molecular Biosensors and Imaging Center, Carnegie Mellon University, Pittsburgh, \\ Pennsylvania 15213
}

The $\delta$ opioid receptor $(\delta \mathrm{R})$ is a promising alternate target for pain management because $\delta \mathrm{R}$ agonists show decreased abuse potential compared with current opioid analgesics that target the $\mu$ opioid receptor. A critical limitation in developing $\delta \mathrm{R}$ as an analgesic target, however, is that $\delta \mathrm{R}$ agonists show relatively low efficacy in vivo, requiring the use of high doses that often cause adverse effects, such as convulsions. Here we tested whether intracellular retention of $\delta \mathrm{R}$ in sensory neurons contributes to this low $\delta \mathrm{R}$ agonist efficacy in vivo by limiting surface $\delta \mathrm{R}$ expression. Using direct visualization of $\delta \mathrm{R}$ trafficking and localization, we define a phosphatase and tensin homolog (PTEN)-regulated checkpoint that retains $\delta \mathrm{R}$ in the Golgi and decreases surface delivery in rat and mice sensory neurons. PTEN inhibition releases $\delta \mathrm{R}$ from this checkpoint and stimulates delivery of exogenous and endogenous $\delta \mathrm{R}$ to the neuronal surface both in vitro and in vivo. PTEN inhibition in vivo increases the percentage of TG neurons expressing $\delta \mathrm{R}$ on the surface and allows efficient $\delta \mathrm{R}-\mathrm{mediated}$ antihyperalgesia in mice. Together, we define a critical role for PTEN in regulating the surface delivery and bioavailability of the $\delta R$, explain the low efficacy of $\delta \mathrm{R}$ agonists in vivo, and provide evidence that active $\delta \mathrm{R}$ relocation is a viable strategy to increase $\delta \mathrm{R}$ antinociception.

Key words: exocytosis; Golgi export; nociception; opioid; trafficking

\section{Significance Statement}

Opioid analgesics, such as morphine, which target the $\mu$ opioid receptor $(\mu \mathrm{R})$, have been the mainstay of pain management, but their use is highly limited by adverse effects and their variable efficacy in chronic pain. Identifying alternate analgesic targets is therefore of great significance. Although the $\delta$ opioid receptor $(\delta \mathrm{R})$ is an attractive option, a critical limiting factor in developing $\delta \mathrm{R}$ as a target has been the low efficacy of $\delta \mathrm{R}$ agonists. Why $\delta \mathrm{R}$ agonists show low efficacy is still under debate. This study provides mechanistic and functional data that intracellular localization of $\delta \mathrm{R}$ in neurons is a key factor that contributes to low agonist efficacy, and presents a proof of mechanism that relocating $\delta \mathrm{R}$ improves efficacy.

\section{Introduction}

The $\delta$ opioid receptor $(\delta \mathrm{R})$ is a prototypical GPCR that is an attractive target for managing neuropsychiatric disorders, including

\footnotetext{
Received Sept. 16, 2016; revised Jan. 26, 2017; accepted Feb. 14, 2017.

Author contributions:D.J.S., A.T., M.D.G., M.S.G., A.A.P., and M.A.P. designed research;D.J.S., A.T., M.D.G., B.F.S., M.S.G., A.A.P., and M.A.P. performed research; B.F.S. contributed unpublished reagents/analytic tools; D.J.S., A.T., M.D.G., M.S.G., A.A.P., and M.A.P. analyzed data; D.J.S., M.S.G., A.A.P., and M.A.P. wrote the paper.

A.A.P. was supported by National Institutes of Health DA031243. M.A.P. was supported by National Institutes of Health Grants DA024698 and GM117425, and National Science Foundation Grant 117776. We thank Claudia Almaguer, Zara Weinberg, and Drs. Rachel Vistein, Amanda Soohoo, Shanna Bowman, and Cary Shiwarski for technical help and comments; Dr. Alison Barth, Joanne Steinmiller, Jen Dry-Henich, Dr. Rebecca Seal, and Adam Goldring for providing help with isolation of TG neurons; Drs. Nathan Urban, Adam Linstedt, Tina Lee, Peter Friedman, Guillermo Romero, Jean-Pierre Vilardaga, and Alessandro Bisello for reagents, comments, and suggestions; and Drs. Mark von Zastrow, John Williams, and Seksiri Arttamangkul for helpful discussions and reagents.

The authors declare no competing financial interests.

Correspondence should be addressed to Dr. Manojkumar A. Puthenveedu, Department of Biological Sciences, Carnegie Mellon University, Pittsburgh, PA 15213. E-mail: map3@andrew.cmu.edu.

DOI:10.1523/JNEUROSCI.2923-16.2017

Copyright $\odot 2017$ the authors $\quad 0270-6474 / 17 / 373741-12 \$ 15.00 / 0$
}

pain, anxiety, and depression. $\delta \mathrm{R}$ expressed in nociceptive neurons can reduce cAMP and inhibit $\mathrm{Ca}^{2+}$ channels to inhibit neuronal activity (Jutkiewicz et al., 2006; Cahill et al., 2007; Pradhan et al., 2011; Bardoni et al., 2014). $\delta$ R agonists can cause antinociception in some conditions, and they show reduced abuse liability compared with current opioids that target the $\mu$ opioid receptor ( $\mu \mathrm{R})$ (Vanderah, 2010; Gendron et al., 2016). $\delta$ R-mediated antinociception in vivo, however, requires high doses approaching concentrations that cause serious adverse effects (Danielsson et al., 2006; Jutkiewicz et al., 2006; Pradhan et al., 2011; Gendron et al., 2016). This low agonist efficacy is a critical limiting factor in developing $\delta \mathrm{R}$ as a drug target.

One explanation for this low efficacy is that there is limited surface $\delta \mathrm{R}$ in nociceptive neurons, where $\delta \mathrm{R}$ is localized mainly to intracellular structures (Svingos et al., 1995; Cheng et al., 1997; Zhang et al., 1998; Petaja-Repo et al., 2000; Cahill et al., 2001a, b; Wang et al., 2001; Bao et al., 2003; Kim and von Zastrow, 2003). 
Several conditions, including inflammation, $\delta \mathrm{R}$ activation, chronic opioid treatment, and pharmacological chaperones, can increase surface $\delta \mathrm{R}$ and "prime" nociceptive neurons for $\delta \mathrm{R}$ antinociception (Stein et al., 1989; Patwardhan et al., 2005, 2006; Gavériaux-Ruff et al., 2008; Rowan et al., 2009; Pettinger et al., 2013; Brackley et al., 2016). This increase in surface $\delta$ R levels can be partly attributed to increased $\delta \mathrm{R}$ levels by higher transcription or translational efficiency (Zhang et al., 1998; Petaja-Repo et al., 2000; Cahill et al., 2001a, b; Wang et al., 2001; Bao et al., 2003; Gendron et al., 2015), raising the possibility that translocating $\delta \mathrm{R}$ to the surface could increase $\delta \mathrm{R}$ agonist efficacy.

Interestingly, in non-neuronal cells, such as undifferentiated PC12 cells, $\delta \mathrm{R}$ expresses well on the cell surface (Kim and von Zastrow, 2003; Gupta et al., 2014). Nerve Growth Factor (NGF), which initiates PC12 differentiation, also triggers intracellular $\delta \mathrm{R}$ retention at relatively short timescales (Kim and von Zastrow, 2003). A major pathway that affects both differentiation and trafficking is the phosphatidylinositol 3 kinase (PI3K)/phosphatase and tensin homolog (PTEN) pathway (Ross et al., 2001; Chen et al., 2012). PI3K adds a phosphate to the 3 ' position on the inositol ring of phosphatidylinositides and profoundly influences trafficking and signaling by recruiting adapters and effectors that specifically bind different phosphorylated species of phosphoinositides (Song et al., 2012; De Matteis and Godi, 2004; Balla et al., 2012). In contrast to the well-studied PI3K, the role of the opposing $3^{\prime}$ phosphatase PTEN in neuronal differentiation and membrane trafficking is less known (Christie et al., 2010; Liu et al., 2010; Song et al., 2012). An increase in PTEN expression, seen at around P7 in mice, is required for the differentiation of neurons in vivo and for NGF-induced differentiation of PC12 cells in culture (Lachyankar et al., 2000; Ross et al., 2001). Interestingly, although acute NGF activates PI3K, persistent NGF downregulates PI3K, facilitating neuronal differentiation (Chen et al., 2012). Paralleling this timescale, long-term NGF increases $\delta \mathrm{R}$ induced inhibition of postsynaptic currents in brainstem slices (Bie et al., 2010), whereas short-term NGF causes intracellular $\delta \mathrm{R}$ retention (Kim and von Zastrow, 2003). Therefore, we hypothesized that the PI3K-PTEN balance might coordinate $\delta$ R surface levels, with 3' phosphoinositides increasing surface delivery and PTEN causing intracellular retention.

In this study, we tested the key prediction of this hypothesis: that inhibiting PTEN will drive $\delta \mathrm{R}$ to the neuronal surface and increase $\delta \mathrm{R}$ agonist efficacy. We show that, in peripheral sensory neurons, PTEN inhibition reduces intracellular $\delta \mathrm{R}$ and increases the functional pool of $\delta \mathrm{R}$ on the neuronal surface both in culture and in vivo. PTEN inhibition increases SNC-80 efficacy in a mouse model of pain without detectable side effects. Together, our results provide an explanation for why $\delta \mathrm{R}$ agonists are largely ineffective in vivo, and a strategy to improve $\delta \mathrm{R}$ antinociception by stimulating surface $\delta \mathrm{R}$ delivery.

\section{Materials and Methods}

Cell lines and DNA constructs. The primary cell line used in this investigation was the pheochromocytoma-12 (PC12) cell line isolated from rat adrenal medulla tissue. This cell line was purchase and verified by ATCC (catalog \#CRL-1721, RRID:CVCL_0481). These cells were cultured in F12K medium (Invitrogen) supplemented with $10 \%$ horse serum and $5 \%$ FBS. Stable and transient PC12 cell lines expressing the full-length $\delta$ R with an $\mathrm{N}$-terminal signal sequence Flag epitope (SSF- $\delta \mathrm{R}$ ) have been created to study the intracellular retention of $\delta \mathrm{R}$ upon NGF $(100 \mathrm{ng} / \mathrm{ml})$ treatment in a fixed cell assay. The full-length $\mu \mathrm{R}$ with an $\mathrm{N}$-terminal signal sequence Flag epitope (SSF- $\mu \mathrm{R}$ ) was used to control for receptor specific effects. For transfection and maintenance of a stable cell lines, the
Table 1. Concentrations and usage specifications

\begin{tabular}{lllll}
\hline $\begin{array}{l}\text { Compound } \\
\text { name }\end{array}$ & Protein target & Concentration & Supplier & Catalog \# \\
\hline $\begin{array}{l}\text { Nerve growth } \\
\text { factor 2.5s }\end{array}$ & TrkA & $100 \mathrm{ng} / \mathrm{ml}$ & BD Biosciences & 356004 \\
SF1670 & PTEN inhibitor & $10 \mu \mathrm{M}$ & Echelon Bioscience & B-0350 \\
bpV (Phen) & PTEN inhibitor & $10 \mu \mathrm{M}$ & Enzo Life Sciences & ALX-270-204-M005 \\
bpV (H0ptic) & PTEN inhibitor & $10 \mu \mathrm{M}$ & Enzo Life Sciences & ALX-270-206-M005 \\
Forskolin & AC activator & $5 \mu \mathrm{M}$ & Tocris Bioscience & 1099 \\
$\beta$-CNA & $\delta$-Opioid & $1 \mu \mathrm{M}$ & Sigma-Aldrich & A00055 \\
& antagonist & & & \\
DADLE & $\delta$ R agonist & $10 \mu \mathrm{M}$ & Tocris Bioscience & 3790 \\
SNC80 & $\delta$ R agonist & $2 \mathrm{mg} / \mathrm{kg}$ & Tocris Bioscience & 0764 \\
\hline
\end{tabular}

lipofection reagent Lipofectamine 2000 (Invitrogen) and the selection antibiotic Geneticin were used.

Pharmacological experimental details. For all fixed-cell pharmacological experiments, the treatments were conducted for $1 \mathrm{~h}$ followed by fixation and immunofluorescence microscopy that is detailed in additional methods. The concentrations and usage specifications are listed in Table 1.

Primary trigeminal ganglion cell isolation. Glass coverslips (Corning) were placed into 6-well plates and precoated with poly D-lysine and laminin to enhance neuron adhesion and promote cell survival before plating. Adult mice (p9-15, C57BL/6J, RRID:IMSR_JAX:000664) were obtained from the animal facility and killed via $\mathrm{CO}_{2}$ asphyxiation. Using large scissors, the head is removed. With small scissors, the skin covering the skull is removed. Cutting away the top of the skull then exposes the brain. The brain is removed by lifting toward the posterior and by cutting cranial nerve $\mathrm{V}$. With the brain removed, the trigeminal ganglia (TG) is visible as longitudinal bundles of tissue. These bundles are cut into small pieces and placed into ice-cold HBSS. A sterile filtered papain solution is applied and incubated for $12 \mathrm{~min}$ at $37^{\circ} \mathrm{C}$. The papain solution is removed, and a dispase/collagenase is applied for $15-20 \mathrm{~min}$ at $37^{\circ} \mathrm{C}$. Upon completion of digestion, the TG tissue is triturated with a fire polished Pasteur pipet 3-5 times, or until the neurons appear visual dissociated. The TG cells are then plated onto the poly D-lysine-coated coverslip within a cloning ring to create a more densely populated cell area. After $5 \mathrm{~h}$, the cloning ring can be removed, and fresh neural basal media (Invitrogen) can be added to each well. The animals were housed in Association for Assessment and Accreditation of Laboratory Animal Care-approved facilities, and studies used protocols that have received institutional review and approval from the Institutional Animal Care and Use Committee at the respective institutions.

Transfection of primary neurons. Lipofectamine 2000 lipofection reagent (Invitrogen) was used per manufacturer's instructions for DNA transfections. Briefly, $2 \mu \mathrm{g}$ of DNA plasmid and 5-7 $\mu \mathrm{l}$ of Lipofectamine reagent were incubated in $250 \mu \mathrm{l}$ of Opti-MEM (Invitrogen) for $5 \mathrm{~min}$ at room temperature. These mixtures were then combined and left to complex for $25 \mathrm{~min}$. The neuronal growth media was removed but saved, and the DNA-Lipofectamine solution was added dropwise to the cells containing $1 \mathrm{ml}$ of additional Opti-MEM and left to incubate at $37^{\circ} \mathrm{C}$ for 4-5 h. Upon completion of the transfection, the reagent-containing medium was removed and replaced with saved neuronal growth medium. Identical conditions and protocol were performed for PC12 cell transfections; however, after transfection, F12K $+10 \%$ horse serum and 5\% FBS-containing medium was used.

Immunofluorescence and fluorescence microscopy. Cells were plated on poly-D-lysine-coated glass coverslips (Corning) and grown for 24-48 h. For PC12 SSF- $\delta$ R intracellular retention experiments, cells were treated with NGF (100 ng/ ml) for $1 \mathrm{~h}$ followed by fixation in 4\% PFA, pH 7.4. The cells were blocked in calcium magnesium containing PBS with 5\% FBS, 5\% $1 \mathrm{~m}$ glycine, and $0.75 \%$ Triton X-100. The SSF- $\delta \mathrm{R}$ was labeled with anti-FLAG M1 antibody (1:1000, Sigma-Aldrich catalog \#F3040, RRID:AB_439712) conjugated with Alexa-647 (Invitrogen catalog \#A-21244 also A21244, RRID:AB_141663), and a trans-Golgi marker, anti-transGolgi network (TGN)-38 (1:2000, Sigma-Aldrich catalog \#T9826, RRID: AB_796176) rabbit polyclonal for $1 \mathrm{~h}$ in the blocking buffer. The coverslips 
were washed 3 times in calcium magnesium PBS followed by addition of Alexa-568 goat anti-rabbit secondary (1:1000, Thermo Fisher Scientific catalog \#A-11011, RRID:AB_143157) antibody in blocking buffer for $1 \mathrm{~h}$. The coverslips were again washed 3 times in calcium magnesium PBS and mounted onto coverslips in calcium magnesium containing anti-fade mounting medium. Following mounting, confocal imaging was performed at $60 \times$ magnification using a Nikon TE-2000 inverted microscope with live-cell imaging capabilities and Andor IQ 2 software (Andor iQ, RRID:SCR_014461). Images of representative fields were taken. For all fixed-cell imaging experiments, a minimum of the average fluorescence ratios of 100 cells was quantified to ensure a representative population. Additionally, a minimum of three biological replicates were performed to confirm all results.

Cycloheximide assay. PC12 SSF- $\delta \mathrm{R}$ cells were plated onto poly-Dlysine-coated coverslips in a 24 -well plate and incubated overnight at $37^{\circ} \mathrm{C}$. NGF $(100 \mathrm{ng} / \mathrm{ml})$ was added to all appropriate samples for $2 \mathrm{~h}$ to achieve complete intracellular retention of $\delta \mathrm{R}$. The media was changed to Opti-MEM + Glutamax (Invitrogen) with cycloheximide $(3 \mu \mathrm{g} / \mathrm{ml})$ for 1 additional hour \pm NGF. The cells were then fixed in $4 \%$ PFA and blocked in the immunofluorescence-blocking buffer. Immunofluorescence of SSF- $\delta \mathrm{R}$ and intracellular compartmental markers were performed as described previously.

Live-cell imaging of NGF-induced retention and PTEN IH release of $\delta R$. To visualize $\delta \mathrm{R}$ in live cells, eGFP was $\mathrm{N}$-terminally tagged to $\delta \mathrm{R}$ in place of the FLAG-tag previously described. PC12 cells or TG neurons were transfected with eGFP- $\delta$ R using Lipofectamine 2000 (Invitrogen) as described previously. Before imaging, cells were transferred to poly-Dlysine-coated coverslips. Cells were imaged at $60 \times$ magnification using a Nikon TE-2000 inverted microscope with a 37 degree heated enclosure and $5 \% \mathrm{CO}_{2}$ environment. Images were acquired every minute for 1.5-2 h. Following $5 \mathrm{~min}$ of baseline imaging, pharmacological treatment was added to the coverslip. The images were analyzed and quantified using Image J analysis software. In live-cell analysis, due to enhanced consistency from internal controls within a cell, a minimum of 10 cells were quantified from three or more biological replicates to provide sufficient statistical power.

Live-cell imaging of cAMP activity. We evaluated activation of $\delta \mathrm{R}$ by its specific agonist [D-Ala2, D-Leu5]-enkephalin (DADLE) with a live-cell Förster resonance energy transfer (FRET) reporter of cAMP, exchange protein directly activated by cAMP (EPAC) (de Rooji et al., 1998; Ponsioen et al., 2004). The EPAC sensor contains a cyan fluorescent protein (CFP) (405 nm excitation, $470 \mathrm{~nm}$ emission) and yellow fluorescence protein ( $515 \mathrm{~nm}$ excitation, $530 \mathrm{~nm}$ emission) (YFP) linked by a cAMP binding domain. When cAMP binds to the sensor, a decrease in the FRET signal (CFP excitation at $405 \mathrm{~nm}$ and yellow fluorescence protein emission at $530 \mathrm{~nm}$ ) is observed. Experiments followed a validated paradigm for cAMP measurements (Sneddon et al., 2000; Bin et al., 2013). Baseline cAMP was stimulated with forskolin $(5 \mu \mathrm{M})$, and subsequent inhibition following $\delta \mathrm{R}$ agonist addition was calculated via the EPAC CFP/FRET ratio. Additionally, blocking the pool of surface receptors with the irreversible $\delta \mathrm{R}$ antagonist, chlornaltrexamine (CNA) $(1 \mu \mathrm{M})$, can prevent the basal surface pool of $\delta \mathrm{R}$ from signaling to isolate the response induced following forced surface trafficking of $\delta \mathrm{R}$.

$\mathrm{Ca}^{2+}$ imaging and electrophysiology. TG neurons from adult female Sprague Dawley rats (Harlan) (RRID:RGD_5508397) were prepared as previously described (Vaughn and Gold, 2010). Two hours after plating, neurons were transferred to an L15-based media (Vaughn and Gold, 2010; Harriott et al., 2012), where they were stored at room temperature for no more than $8 \mathrm{~h}$. For $\mathrm{Ca}^{2+}$ imaging, neurons were loaded with fura-2 AM in pluronic F127 as previously described (Lu et al., 2006). They were then transferred to bath solution containing vehicle or $\mathrm{bpV}$ (Phen) $(10 \mu \mathrm{M})$ where they were incubated at $35^{\circ} \mathrm{C}$ for $30 \mathrm{~min}$ before study. Depolarization-induced $\mathrm{Ca}^{2+}$ transients were evoked with high $\mathrm{K}^{+}(30 \mathrm{~mm}, 800 \mathrm{~ms})$ every $2 \mathrm{~min}$. SNC80 $(1 \mu \mathrm{M})$ was then applied $1 \mathrm{~min}$ before the application of SNC80 with high $\mathrm{K}^{+}$. The variance around the mean baseline response of all neurons studied in each group was used to identify neurons responsive to SNC80, where a decrease $>2$ SDs from the mean change observed at baseline was considered a response to SNC80. At the end of each experiment, neurons were challenged with capsaicin
(500 nм for $500 \mathrm{~ms}$ ). Neurons used for voltage-clamp experiments were processed in the same way as those used for $\mathrm{Ca}^{2+}$ imaging, except they were not loaded with fura-2. Inclusion/exclusion criteria were preestablished and were based on the resting $\mathrm{Ca}^{2+}$ levels, which in healthy neurons is $<150 \mathrm{nM}$, the stability of the magnitude of the evoked $\mathrm{Ca}^{2+}$ transient, which, in healthy neurons, is neither consistently increasing nor consistently decreasing over at least 3 applications of high $\mathrm{K}^{+}$at an interstimulus interval of $3 \mathrm{~min}$, and the rate at which in intracellular $\mathrm{Ca}^{2+}$ level returns to baseline after each depolarizing evoked transient, where the recovery is complete within $4 \mathrm{~min}$ in healthy neurons. Voltagegated $\mathrm{Ca}^{2+}$ currents were recorded with bath and electrode solutions composed to minimize voltage-gated $\mathrm{Na}^{+}$and $\mathrm{K}^{+}$currents, as previously described (Vaughn and Gold, 2010). Currents were evoked from a holding potential of $-60 \mathrm{mV}$, to a test potential of $-5 \mathrm{mV}$ every $5 \mathrm{~s}$. When currents stabilized after obtaining whole-cell access, SNC80 $(1 \mu \mathrm{M})$ was applied via a gravity perfusion system. A decrease $>2$ times the SD from the mean baseline current was considered a response to SNC80.

Fluorescent deltorphin II-Cy3.29. A cysteine-extended Deltorphin II was custom ordered from www.Lifetein.com for conjugation to Cy3.29 maleimide. Cysteine-extended Deltorphin II (7 mg) was dissolved in $2 \mathrm{ml}$ of dry DMF. Cy3.29 maleimide ( $10.5 \mathrm{mg}=1.5$ equivalents) was dissolved in $2 \mathrm{ml}$ dry Dimethylformamide (DMF). The Deltorphin II and Cy3.29 maleimide solutions were combined with the addition of diisopropylethylamine $(60 \mu \mathrm{l})$ to keep the reaction from acidifying. The reaction mixture was kept at $37^{\circ} \mathrm{C}$ for $2 \mathrm{~h}$ and then left it at room temperature overnight. The reaction mixture was added drop wise to $50 \mathrm{ml}$ of ethyl acetate to precipitate the product and remove the DMF. The organic phase was decanted. The residue containing the Cy3-labeled Deltorphin II was purified by HPLC on a $\mu$-Bondapak C18 $7.8 \times 300 \mathrm{~mm}$ column; flow $3 \mathrm{ml} / \mathrm{min}$; acetonitrile/water $0.1 \%$ TFA gradient. The product peak was further analyzed by UPLC on an Acquity BEH C18 column $1.7 \mu$ $2.1 \times 50 \mathrm{~mm}$. Following product fraction collection, the $\mathrm{pH}$ was adjusted to 8.4 with sodium bicarbonate and concentrated to a volume of $2 \mathrm{ml}$. The product was desalted by loading the solution on a Waters Sep-Pak C18 column, washing with $5 \mathrm{ml}$ of water and eluting the product with 4 $\mathrm{ml}$ of water $/ 20 \%$ ethanol. The final product solution was lyophilized to give $2 \mathrm{mg}$ of high purity Cy3 maleimide-labeled Deltorphin II. The product was further characterized my mass spectrometry on a Thermo Fisher LTQ-XL ESI/APCI Linear Ion Trap instrument. The final molecular weight of the cysteine-extended Deltorphin II Cy3.29 was 1637.9.

In vivo PTEN IH and surface receptor quantification. To establish a time point in mice (C57BL/6J, RRID:IMSR_JAX:000664) for PTEN IHinduced surface trafficking of $\delta \mathrm{R}$ and visualize newly trafficked receptors, we subcutaneously injected a saline control, or the PTEN IH bpV(Phen) at $3 \mathrm{mg} / \mathrm{kg}$, and returned the mice to their home cage. At $2 \mathrm{~h}$ intervals (2, $4,6 \mathrm{~h}$ ), TG neurons were dissociated following the aforementioned protocol. Instead of plating onto coverslips for in vitro culturing, we isolated the dissociated neurons and incubated them with Deltorphin II Cy3 (100 $\mathrm{nM}$ ) and Hoechst stain for $10 \mathrm{~min}$ on ice. The neurons were then centrifuged at $5 \times$ gravity and washed with PBS. The labeled neuron suspension was then transferred to a coverslip for live-cell confocal imaging performed at $37^{\circ} \mathrm{C}$ and $20 \times$ magnification using a Nikon TE-2000 inverted microscope. The percentage of Hoechst-positive Deltorphin II Cy3expressing cells was determined at each time point.

In vivo analgesia assay. Subjects were male C57BL/6J mice (RRID: IMSR_JAX:000664), between 9 and 12 weeks old. Mechanical hyperalgesia was tested using the manual von Frey test following standard protocols established by the Pradhan laboratory (Pradhan et al., 2013). Baseline mechanical responses were determined, and inflammatory pain was induced by injecting $13 \mu \mathrm{l}$ of CFA into the plantar surface of the left hindpaw. On the test day, mice were randomly allocated to different test groups and injected with vehicle or bpV (Phen) (3 mg/kg s.c.), and returned to their home cages. Four hours after injection, mice were injected with vehicle or SNC80 (2 mg/kg i.p.) and mechanical hyperalgesia was assessed $45 \mathrm{~min}$ later. To confirm specificity to $\delta \mathrm{R}$, we treated mice with naltrindole $(10 \mathrm{mg} / \mathrm{kg}$, s.c.), a $\delta$ R-selective antagonist, $1 \mathrm{~h}$ before SNC80. The investigator was partially blinded and was not aware whether animals received $\mathrm{bpV}$ (Phen) or vehicle. All experiments were done in ac- 

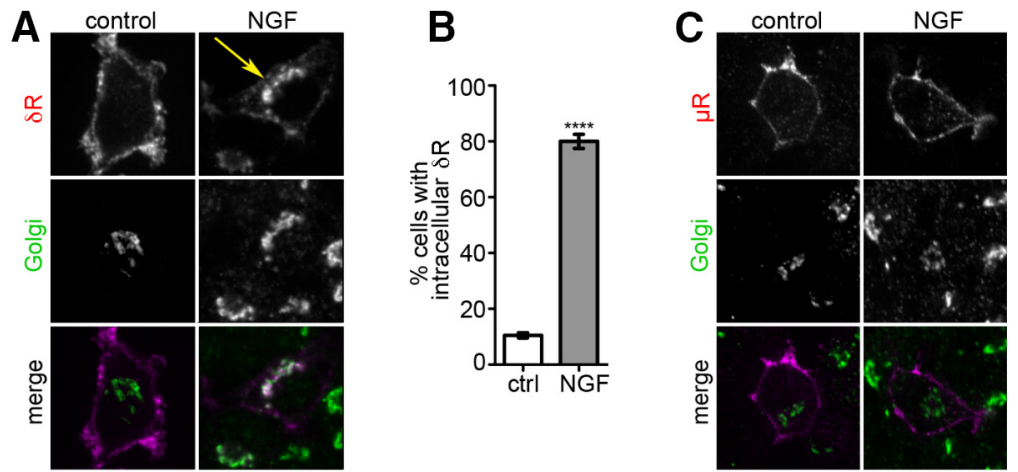

D

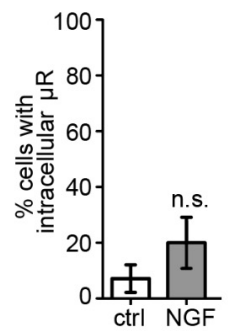

E

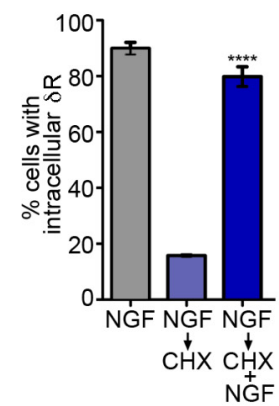

F

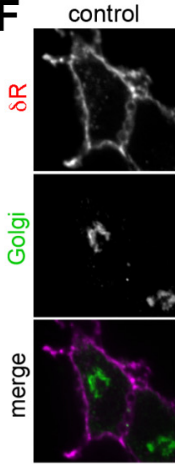

NGF

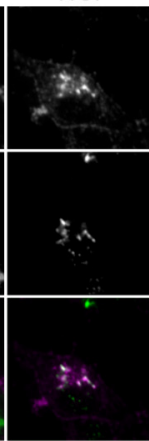

$\mathrm{NGF}+\mathrm{SF}$

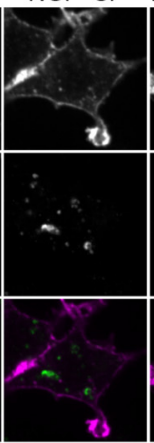

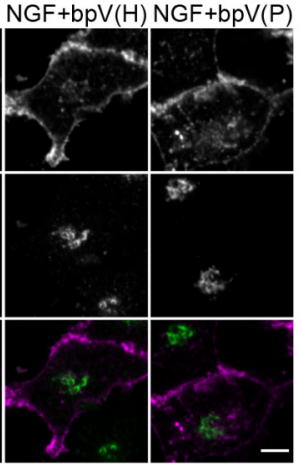

G

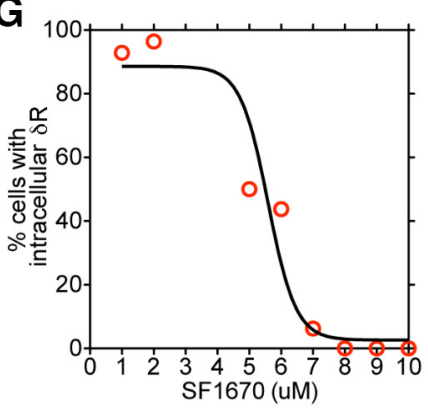

H

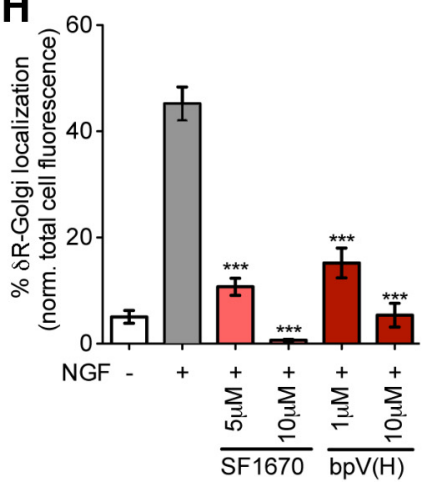

Figure 1. PTEN inhibition releases Golgi-retained $\delta R$ and promotes surface delivery in $\mathrm{PC} 12$ cells. $A$, Example images of $\mathrm{PC} 12$ cells showing surface $\delta R$ expression (red in merge) and intracellular accumulation of FLAG- $\delta R$ (arrow) after NGF treatment ( $60 \mathrm{~min}$ at $100 \mathrm{ng} / \mathrm{ml}$ ), colocalizing with TGN-38 (Golgi, green in merge). B, Quantitation showing an increase in the percentage of cells with $\delta R$ Golgi localization after NGF ( $n>100$ cells each). Data are mean \pm SEM. **** $<0.0001$. C, Example image of a PC12 cell showing surface FLAG- $\mu$ R as a control. NGF treatment (60 min at 100 $\mathrm{ng} / \mathrm{ml}$ ) causes no internal $\mu \mathrm{R}$ accumulation. $\boldsymbol{D}$, Quantitation showing that NGF does not increase the percentage of cells showing $\mu R$ retention ( $n>50$ cells each). Data are mean \pm SEM. $E$, NGF-treated PC12 cells, chased with cycloheximide (CHX) for $1 \mathrm{~h}$ in the presence and absence of NGF, to isolate the effect of NGF independent of $\delta$ R biosynthesis and transport. The percentage of cells with Golgi-localized $\delta R$ is shown ( $n>100$ cells in each condition). Data are mean \pm SEM. ${ }^{* * *} p<0.0001$, CHX treatments with NGF versus without NGF. $F$, Example images for control and NGF-treated PC12 cells with inhibition of PTEN by $10 \mu \mathrm{m}$ of SF1670 (SF), bpV HOptic (bpV(H)), or bpV (Phen) (bpV(P)). PTEN inhibition abolishes Golgi retention of $\delta R$. G, A dose-dependent effect of SF1670-mediated loss of Golgi-localized $\delta R$ in NGF-treated PC12 cells. $\boldsymbol{H}$, Image analysis and quantification show a significant reduction in the percentage of total $\delta R$ fluorescence that overlaps with the Golgi upon PTEN inhibition ( $n>100$ cells each). Data are mean \pm SEM. ${ }^{* *} p<0.001$.

cordance with Institutional Animal Care and Use Committee-approved protocols at the respective institutions. Animals were housed in Association for Assessment and Accreditation of Laboratory Animal Careapproved facilities with unrestricted access to food and water.

Statistics and data analysis. Statistical analyses were performed using Prism 5 software (GraphPad, RRID:SCR_002798), and appropriate statistical tests were chosen based on sample size and distribution. For statistical analysis of the quantified imaging data, two-tailed unpaired $t$ tests were performed between the different experimental conditions and controls. For calcium imaging in neurons, sample size was based on a preliminary analysis of control neurons in which we determined the proportion of neurons in three fields of view from each of 2 animals, that were responsive to $\mathrm{SNC} 80$, where a neuron was considered responsive to SNC80 if the depolarization evoked $\mathrm{Ca}^{2+}$ transient in the presence of SNC80 was reduced by $>2$ SDs from the mean of at least 3 transients evoked before the application of SNC80. These preliminary results were used in a power analysis in which we estimated the number of neurons needed to detect a significant increase in the proportion of SNC80responsive neurons. To compare the population changes in $\delta \mathrm{R}$-positive neurons, a two-tailed Fisher's Exact test was performed. For the animal data, a power analysis was performed based upon our initial experiment, and a sample size of $>5$ was estimated to be adequate. We choose to have our minimum sample size be 10 to exceed concerns due to limited sample size. To analyze the significance of the in vivo animal data, a one-way nonparametric ANOVA was performed followed by a Kruskal-Wallis post-test comparing all columns. A $p$ value of $<0.05$ was considered statistically significant. All images were quantified using macros contained within the ImageJ software package (ImageJ, RRID:SCR_003070).
Figures were constructed with ImageJ and Adobe Photoshop CS6 (Adobe Photoshop, RRID:SCR_014199).

\section{Results}

PTEN inhibition drives $\delta \mathrm{R}$ relocation to the surface in

\section{TG neurons}

We initially used neuroendocrine PC12 cells expressing N-terminally FLAG-tagged $\delta \mathrm{R}$ as an experimental system to start addressing regulated $\delta \mathrm{R}$ trafficking. This expression system has been highly useful to study many GPCRs, including $\delta$ R, and we and others have confirmed that tagged receptors are functional (Guan et al., 1992; Kim and von Zastrow, 2003; Arttamangkul et al., 2008; Puthenveedu et al., 2010; Soohoo and Puthenveedu, 2013; Vistein and Puthenveedu, 2013; Bowman et al., 2015). Consistent with previous observations, FLAG- $\delta \mathrm{R}$ expressed in PC12 cells showed predominantly surface expression (Fig. $1 A$ ). NGF treatment for $1 \mathrm{~h}$ caused $\delta \mathrm{R}$ accumulation in an intracellular compartment broadly overlapping with the TGN marker TGN-38 (Fig. 1A). Quantitation of the fraction of cells with intracellular $\delta \mathrm{R}$ showed a significant increase after NGF treatment (Fig. 1B). This intracellular accumulation was not a general effect, as NGF did not induce accumulation of the related $\mu$ opioid receptor (FLAG- $\mu \mathrm{R}$ ) under identical conditions (Fig. $1 C, D$ ). To establish that this was a transport block of newly synthesized receptors, we first accumulated $\delta \mathrm{R}$ in the TGN by treating cells with NGF for $1 \mathrm{~h}$ to induce Golgi retention, and then chased this accumulated pool by block- 

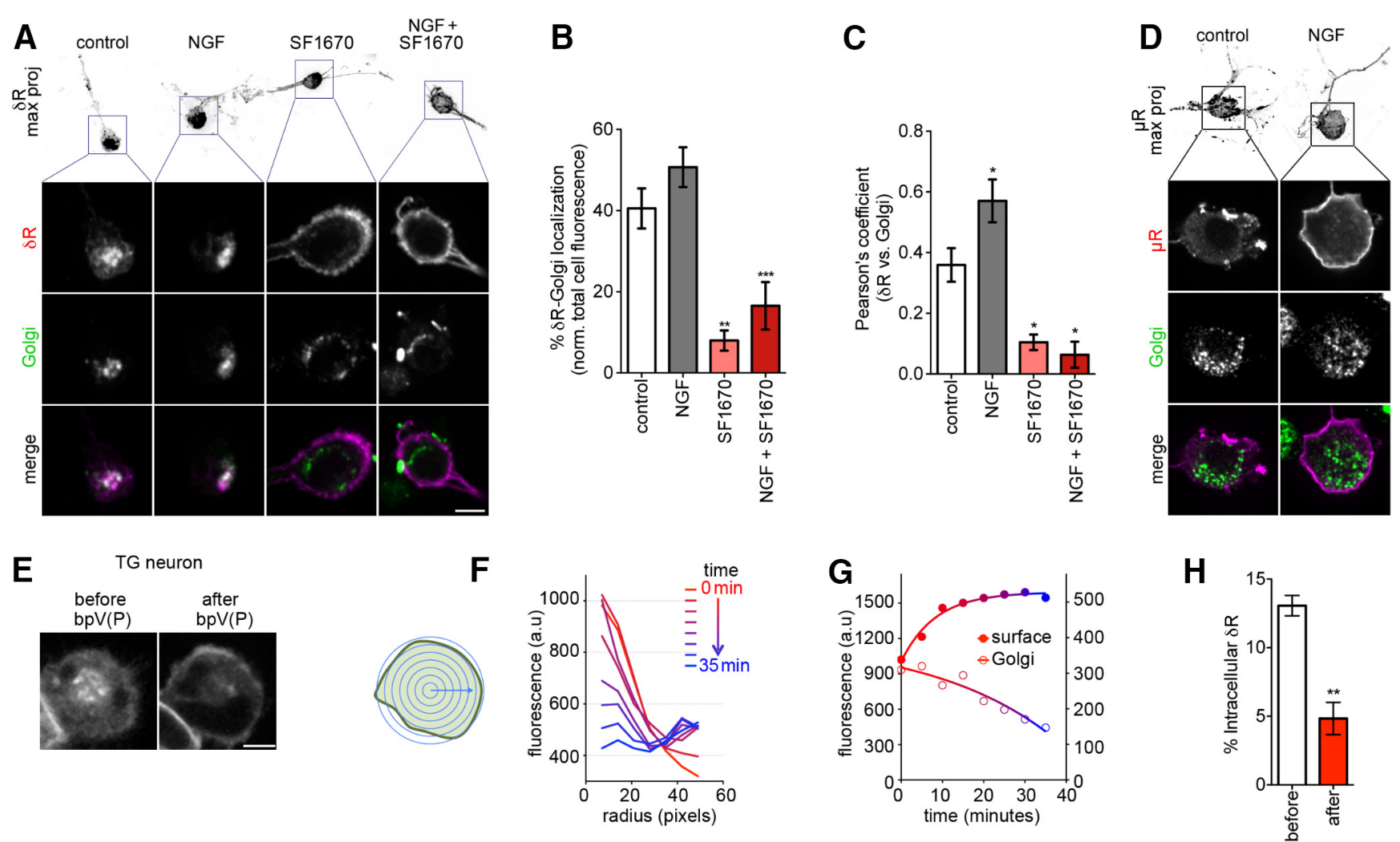

Figure 2. PTEN inhibition releases Golgi-retained $\delta$ R and promotes surface delivery in TG neurons. $A$, Example immunofluorescence images demonstrating the localization of expressed FLAG- $\delta R$ in mouse TG neurons with or without NGF (100 ng/ml for $1 \mathrm{~h}$ ), with and without the PTEN inhibitor (SF1670, $10 \mu \mathrm{m})$. PTEN inhibition drives $\delta R$ to the surface. $\boldsymbol{B}$, The fraction of Golgi-localized $\delta R$ in primary TG neurons decreased significantly upon PTEN inhibition (SF1670, $10 \mu \mathrm{M})\left(n>10\right.$ neurons each). Data are mean $\pm S E M .{ }^{* *} p<0.01$. ${ }^{* * *} p<0.001$. C, Pearson's correlation coefficients show decreased colocalization between $\delta R$ and the Golgi upon SF1670 addition ( $n>10$ neurons each). Data are mean $\pm S E M .{ }^{*} p<0.05$. $D$, Example immunofluorescence images of expressed FLAG- $\mu R$ in mouse TG neurons with or without NGF ( $100 \mathrm{ng} / \mathrm{ml}$ for $1 \mathrm{~h}$ ). $\mu R$ was localized to the surface with minimal intracellular fluorescence. $E$, Example frames from a live-cell movie of mouse TG neurons expressing GFP- $\delta$ R before and after addition of PTEN inhibitor bpV(Phen) $(10 \mu \mathrm{M}) . \boldsymbol{F}$, Radial profile analysis of the images (schematic) revealed a decrease in the fluorescence intensity of the center and an increase in the periphery over time following PTEN inhibition (added at $t=1 \mathrm{~min}$ ). Time is depicted as a color gradient from red to blue. G, PTEN inhibition causes an increase in GFP- $\delta R$ fluorescence on the surface and a decrease in fluorescence in Golgi regions. $\boldsymbol{H}$, Quantitation across multiple neurons shows a decrease in the percentage of intracellular $\delta R$ normalized to the total cell fluorescence $(n=10)$. Data are mean \pm SEM. ${ }^{* *} p<0.01$. Scale bars, $5 \mu \mathrm{m}$.

ing the synthesis of new $\delta \mathrm{R}$ with cycloheximide. This chase was performed either in the absence or presence of continued NGF. The intracellular pool was rapidly chased out in the absence of NGF, but, in the presence of NGF, it persisted even when the synthesis of new $\delta \mathrm{R}$ was blocked, indicating that NGF signaling blocks export of $\delta \mathrm{R}$ from these intracellular compartments that overlap with the Golgi (Fig. 1E).

We next asked whether PTEN inhibition would block NGFmediated $\delta \mathrm{R}$ retention in this experimental system. We tested three different PTEN inhibitors, SF1670, bpV(HOptic), and $\mathrm{bpV}($ Phen), all of which abolished NGF-induced $\delta \mathrm{R}$ retention and induced surface $\delta \mathrm{R}$ delivery (Fig. $1 F$ ). Quantitation of the fraction of cells with intracellular $\delta \mathrm{R}$ showed a dose-dependent decrease with SF1670. As a more objective index of intracellular retention of $\delta \mathrm{R}$, we quantitated the fraction of total cellular $\delta \mathrm{R}$ that overlapped with TGN-38, using TGN-38 fluorescence as a mask. The fraction of $\delta \mathrm{R}$ that was retained in response to NGF was significantly attenuated by PTEN inhibition (Fig. $1 H$ ), indicating that PTEN inhibition can counter NGF-induced retention of $\delta R$.

Importantly, we next tested whether PTEN inhibition could drive the intracellular pool of $\delta \mathrm{R}$ to the cell surface in physiologically relevant TG neurons. We cultured TG neurons isolated from adult mice and transfected them with FLAG- $\delta$ R. Because previous reports indicated that $\delta \mathrm{R}$ was predominantly expressed intracellularly in small-diameter neurons, we limited our experiments to neurons with a diameter between 10 and $20 \mu \mathrm{m}$ (Wang et al., 2010; Pettinger et al., 2013). Consistent with these reports, FLAG- $\delta \mathrm{R}$ was predominantly seen in intracellular compartments that overlapped with the Golgi in these neurons (Fig. 2A). NGF treatment for $1 \mathrm{~h}$ did not significantly modify the localization of FLAG- $\delta$ R or of PTEN, which showed a diffuse cytoplasmic distribution. Treatment with the PTEN inhibitor SF1670 for $1 \mathrm{~h}$ caused a loss of intracellular FLAG- $\delta$ R localization and the appearance of $\delta \mathrm{R}$ on the surface of neurons, regardless of whether NGF was present or not (Fig. 2A). This loss corresponded with a significantly higher fraction of neurons that showed surface FLAG- $\delta$ R fluorescence $($ Control $=28.57 \pm 12.53 \%$; PTEN IH $=$ $92.86 \pm 7.14 \% ; p<0.001)$. Quantitation of the fraction of $\delta \mathrm{R}$ that overlapped with the Golgi showed a significant decrease after PTEN inhibition (Fig. 2B). This loss of intracellular $\delta \mathrm{R}$ was also detected as a loss of colocalization between the Golgi marker and FLAG- $\delta$ R, as measured by Pearson's coefficients across cells (Fig. $2 C)$. As a control, FLAG- $\mu$ R expressed in TG neurons, and analyzed in an identical manner, did not show intracellular receptor pools, regardless of whether NGF was added or not (Fig. 2D). This suggests that the intracellular localization is an active process that is specific for $\delta \mathrm{R}$. We next directly visualized the redistribution of $\delta \mathrm{R}$ in neurons following PTEN inhibition, by live-cell confocal microscopy of mouse TG neurons expressing GFP- $\delta$ R. 
$\mathbf{A}_{\mathrm{CFP}}$

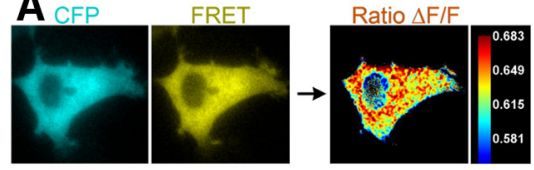

$\delta R$ (anti-FLAG)

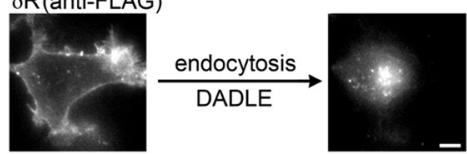

B

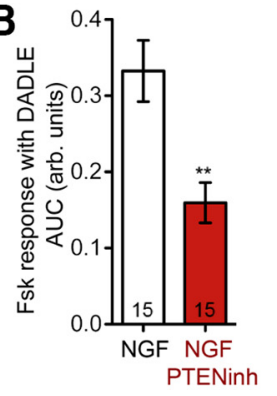

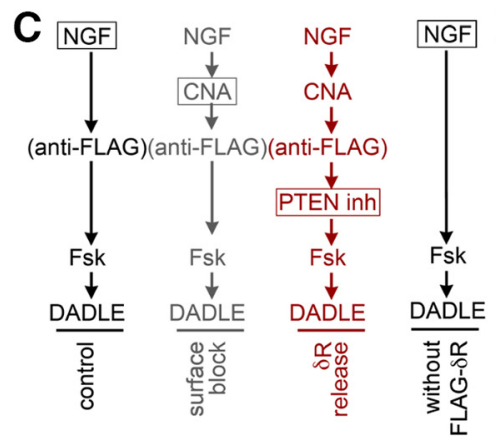

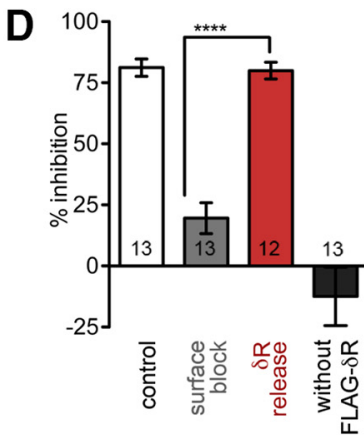

E

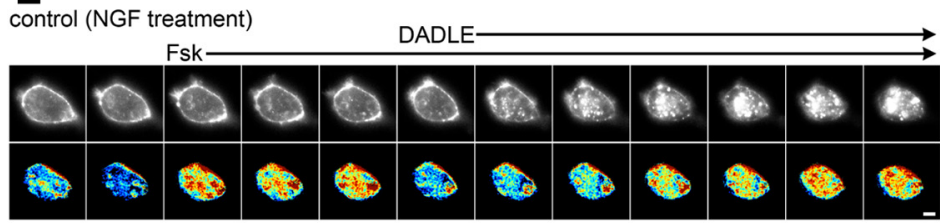

G

surface block (CNA)
Fsk

I

$\delta \mathrm{R}$ release (PTEN inh)

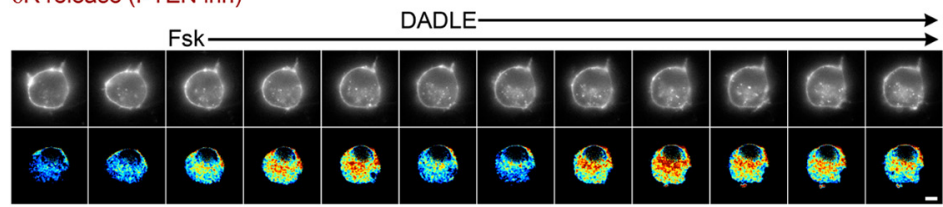

F

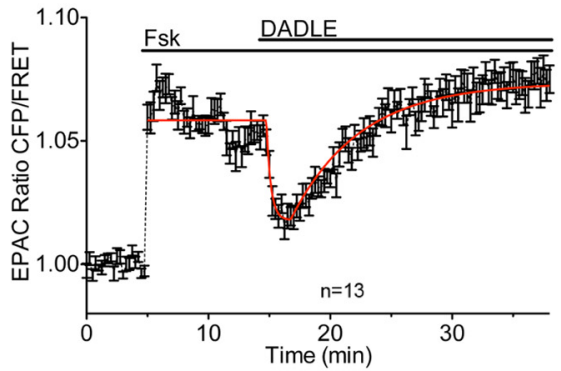

H

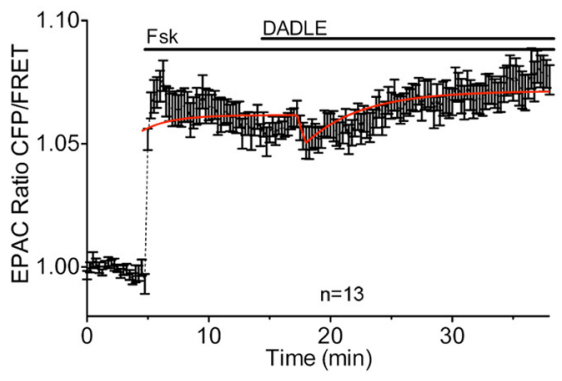

J

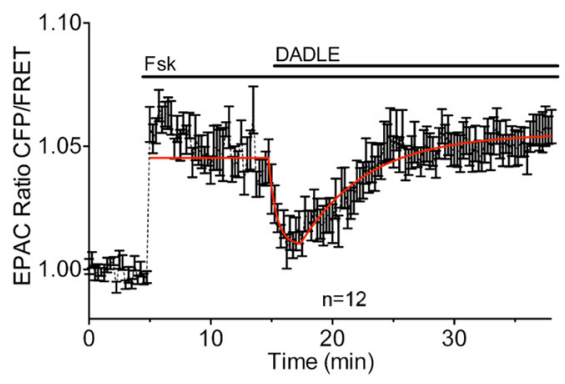

Figure 3. The $\delta R$ delivered to the surface by PTEN inhibition is competent to inhibit CAMP.A, Schematic of ratiometric analysis for cAMP measurement using the Epac sensor. The CFP, FRET, and FLAG- $\delta$ R were imaged and followed live in the same PC12 cells. FRET ratio image is mapped to blue for low CAMP and red for high cAMP. $\boldsymbol{B}$, Inhibition of Fsk-mediated increases in CAMP by DADLE was measured as an index of the activity of surface $\delta$ R. In NGF-treated PC12 cells, DADLE-mediated inhibition was significantly enhanced by PTEN inhibition (SF1670, $10 \mu \mathrm{M}$ ), as seen by a lower Fsk response $\left(n>15\right.$ each). Data are mean \pm SEM. ${ }^{* *} p<0.01$. C, Schematic of experiments to isolate the functional effect of $\delta R$ delivery by PTEN inhibition after surface $\delta R$ is blocked by CNA (1 $\mu \mathrm{M}$ ). $D$, The percentage of inhibition of cAMP response under the four conditions shows recovery of DADLE-mediated inhibition by PTEN inhibition after surface $\delta R$ is blocked by CNA, and that the inhibition requires $\delta R$. Data are mean \pm SEM. ${ }^{* * *} p<0.0001$. $E-J$, Example images $(\boldsymbol{E}, \boldsymbol{G}, \boldsymbol{I})$ from a time lapse movie showing FRET changes and $\delta R$ localization after DADLE in the three experimental conditions. The average FRET change $(\boldsymbol{F}, \boldsymbol{H}, \boldsymbol{J})$ over time from multiple cells for each experimental condition is shown. Red lines indicate curve fits for the Fsk response, DADLE response, and desensitization, over time. Error bars indicate SEM. Scale bars, $5 \mu \mathrm{m}$.

In TG neurons, GFP- $\delta$ R was primarily localized to intracellular pools, with minimal surface localization. PTEN inhibition by $\mathrm{bpV}(\mathrm{Phen})$ induced loss of the intracellular $\delta \mathrm{R}$ pool and increased the membrane localization (Fig. 2E). A radial profile analysis for each time point showed, quantitatively, that the fluorescence intensity for the intracellular pool (smaller radii) decreases and the plasma membrane (larger radii) increased (Fig. $2 F, G$ ). Quantitation of intracellular $\delta$ R fluorescence in multiple neurons showed a significant decrease in the intra- cellular $\delta \mathrm{R}$ pool after PTEN inhibition (Fig. $2 H$ ). These data demonstrate that PTEN inhibition reduces intracellular $\delta \mathrm{R}$ retention and stimulates $\delta \mathrm{R}$ surface trafficking in mouse TG neurons.

$\delta \mathrm{R}$ delivered to the surface by PTEN inhibition is competent for signaling

To test whether PTEN inhibition increased functional $\delta \mathrm{R}$ on the surface, we measured cAMP inhibition by $\delta \mathrm{R}$ as a primary readout of 
A

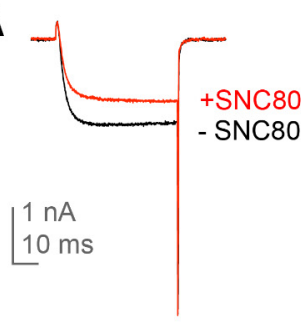

B

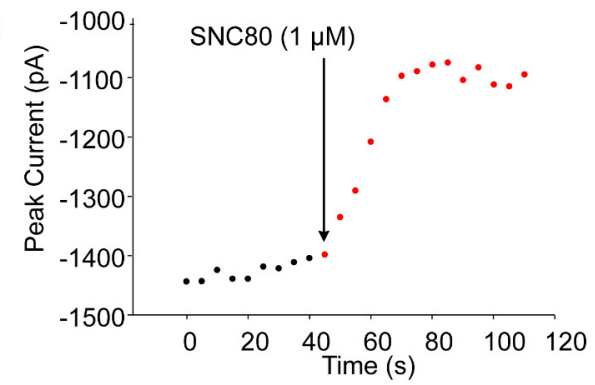

C

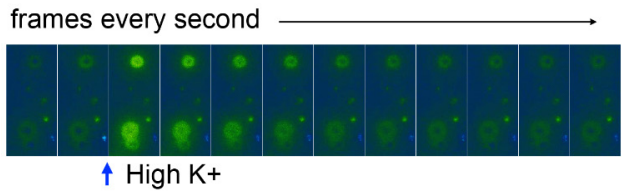

D

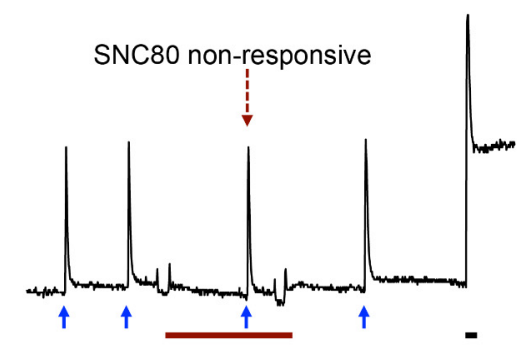

E

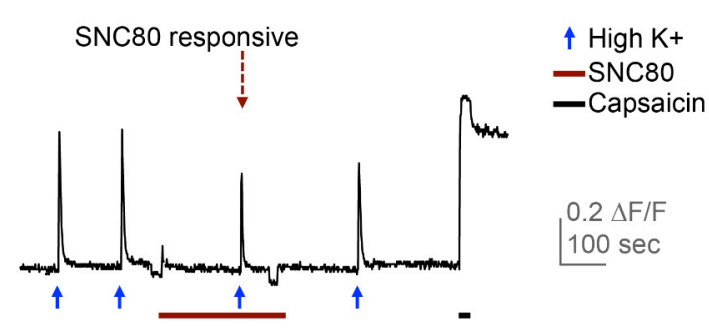

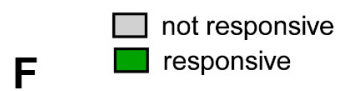

responsive

Figure 4. PTEN inhibition increases the functional pool of endogenous $\delta \mathrm{R}$ in TG neurons. $\boldsymbol{A}$, Example calcium current traces from a voltage-clamped rat TG neuron after PTEN inhibition, before and after SNC80, showing robust decrease in current after SNC80. B , Time course of decrease in current after SNC80 bath application to a TG neuron after PTEN inhibition. C, Live imaging of calcium transients of rat TG neurons in response to high K, detected by fura-2 AM loading. $\boldsymbol{D}, \boldsymbol{E}$, Example traces of fura- 2 AM responses showing a neuron that is nonresponsive to SNC80 ( $\boldsymbol{D}$ ) and one that is responsive $(\boldsymbol{E})$. $\boldsymbol{F}$, Quantification of the fraction of neurons that respond to SNC80 with and without pretreatment with bpV(Phen). The number of cells in each condition is noted. PTEN inhibition induced a significant increase in the fraction of neurons that respond to SNC80. ${ }^{* * * *} p<0.0001$.

Gi coupling. Dynamic changes in cAMP levels were detected using the EPAC FRET sensor (DiPilato et al., 2004), simultaneously with activation and endocytosis of $\delta \mathrm{R}$ (Fig. $3 A$ ). $\delta \mathrm{R}$ activation was measured as attenuation of forskolin-stimulated cAMP. In NGF-treated PC12 cells expressing the FLAG- $\delta$ R, PTEN inhibition caused a stronger inhibition of cAMP in response to DADLE, which was $\sim 48 \%$ lower than the NGF only response, consistent with increased availability of $\delta \mathrm{R}$ on the surface (Fig. $3 B$ ).

To directly test whether the increase in activity was due to release of NGF-retained $\delta$ R by PTEN inhibition, we blocked preexisting surface $\delta \mathrm{R}$ with the irreversible antagonist CNA. This allowed us to isolate signaling from newly delivered receptors in a defined period of time (schematic in Fig. 3C). Following NGFinduced $\delta \mathrm{R}$ retention, pretreatment with CNA significantly reduced DADLE-mediated $\delta \mathrm{R}$ endocytosis and cAMP inhibition, from $\sim 80 \%$ to $20 \%$, in cells expressing $\delta$ R (Fig. $3 D$ ). Following the NGF-induced $\delta$ R retention and CNA blockade of surface $\delta$ R, PTEN inhibition was sufficient to recover agonist-induced $\delta \mathrm{R}$ signaling back to $\sim 80 \%$ (Fig. $3 D$, time series in Fig. $3 E-J$ ). In PC1 2 cells not exogenously expressing the FLAG- $\delta$ R construct, DADLE did not inhibit the forskolin-stimulated cAMP, instead causing a $12 \pm 11 \%$ increase (Fig. $3 D$ ), confirming that, in FLAG- $\delta$ R cells, cAMP inhibition in response to DADLE is specific to $\delta \mathrm{R}$. Together, our data indicate that the $\delta \mathrm{R}$ delivered to the surface from intracellular pools by PTEN inhibition was competent to bind agonists and induce signaling.

To test whether PTEN inhibition induced an increase in the levels of endogenous functional $\delta \mathrm{R}$ in neurons, we evaluated the ability of PTEN inhibition to increase the $\delta \mathrm{R}$-mediated inhibition of evoked calcium channel transients in adult rat TG neurons. Following pretreatment of isolated TG neurons with the PTEN inhibitor bpV(Phen) for $30 \mathrm{~min}$, agonist-induced (SNC-80) activation of $\delta \mathrm{R}$ caused a robust inhibition of $\mathrm{Ca}^{2+}$ transients (Fig. $4 A, B)$. To better quantitate the effect of PTEN inhibition, we used the calcium indicator dye fura-2 AM to measure high $\mathrm{K}^{+}$ evoked responses in neurons before and after $\delta \mathrm{R}$ activation. $\mathrm{KCl}-$ induced $\mathrm{Ca}^{2+}$ transients were observed as a brief increase in fluorescence intensity followed by decay over time (Fig. 4C). Neurons were then characterized as either nonresponsive (Fig. $4 D$ ) or responsive (Fig. $4 E$ ) based on the decrease in evoked $\mathrm{KCl}$ induced $\mathrm{Ca}^{2+}$ transients following SNC80 (calculated as more than twice the SD of the initial responses). The percentage of neurons that responded to the $\delta \mathrm{R}$ agonist SNC80 increased significantly following pretreatment with the PTEN inhibitor bpV(Phen), compared with control neurons ( $\sim 52 \%$ responders following PTEN inhibition compared with $\sim 13 \%$ in control) (Fig. 4F). The magnitude of inhibition across TG neurons did not change significantly. As a control, PTEN inhibition did not increase the fraction of TG neurons that responded to capsaicin in this same pool. A similar trend of increased responses to SNC80 was also observed in adult mouse DRG neurons. Interestingly, in DRG neurons, the magnitude of SNC80-mediated inhibition increased from $29 \pm 3.4 \%$ in control neurons to $38 \pm$ $4.3 \%$ after PTEN inhibition, indicating that the resting levels of $\delta \mathrm{R}$ might vary between neuronal cell types or species. As a control, PTEN inhibition did not change the fraction of responding neurons or the magnitude of inhibition by DAMGO in DRG neurons $(50.1 \pm 3.2$ in control neurons and $47.0 \pm$ $2.9 \%$ after PTEN inhibition). Together, our results demonstrate that, by driving endogenous $\delta$ R to the surface through PTEN inhibition, we can increase functional responses of peripheral neurons to $\delta \mathrm{R}$ agonists. 
A

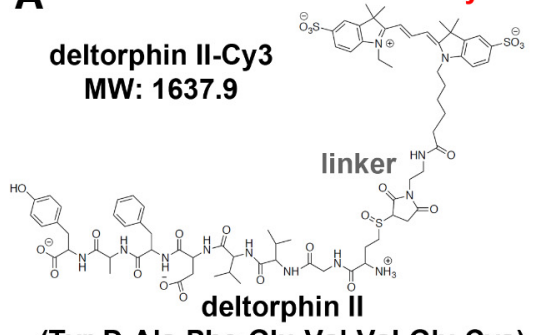

(Tyr-D-Ala-Phe-Glu-Val-Val-Gly-Cys)

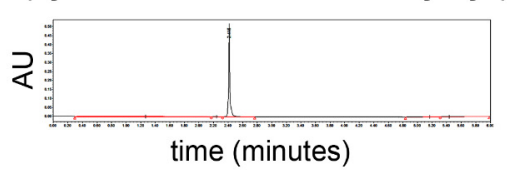

B

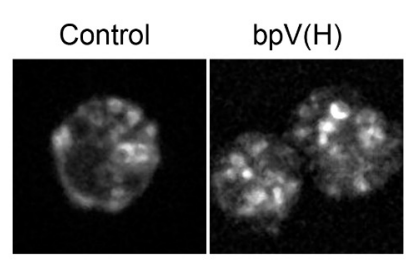

C

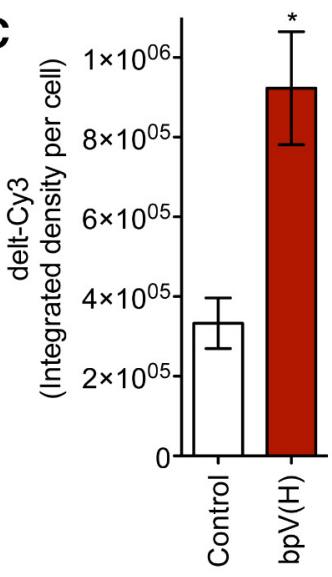

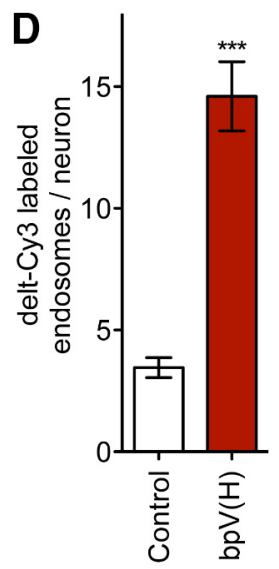

$E$

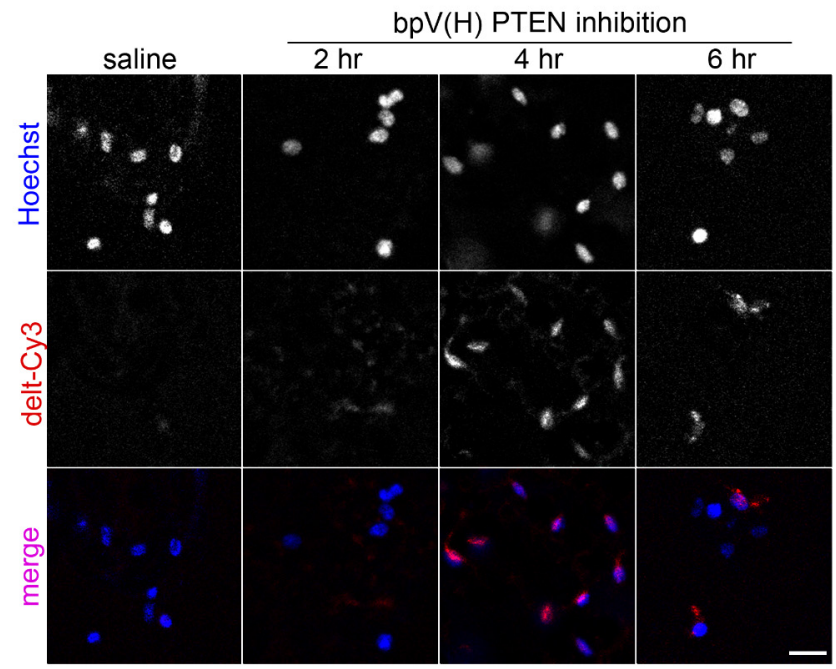

$\mathbf{F}$

delt-Cy3 negative

delt-Cy3 positive

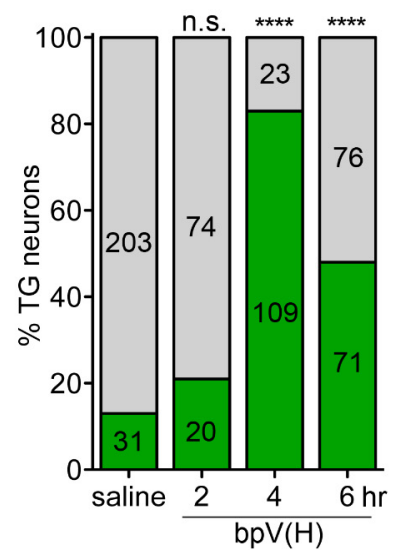

Figure 5. PTEN inhibition increases the functional surface pool of endogenous $\delta$ R in TG neurons in vivo. $\boldsymbol{A}$, Structure of the $\delta$ R-specific agonist Deltorphin II C-terminally conjugated to Cy3. The final UPLC purification spectrum is shown below and demonstrates a single pure product peak. $\boldsymbol{B}$, Example images (of $n=3$ independent experiments) are shown of cultured mouse TG neurons that were preincubated with delt-Cy3 for $10 \mathrm{~min}$ following $1 \mathrm{~h}$ control and PTEN inhibitor (bpv(Phen) $10 \mu \mathrm{m}$ ) treatment conditions. Scale bars, $5 \mu \mathrm{m}$. C, Quantitation across multiple cells shows that the delt-Cy3 fluorescence integrated density per cell increases following PTEN inhibition (Control, $n=10$ neurons; bpV(H), $n=29$ neurons). Data are mean \pm SEM. ${ }^{*} p<0.05$ (two-sided $t$ test vs Control). $\boldsymbol{D}$, The number of delt-Cy3-positive endosomes per neuron increased following PTEN inhibition (Control, $n=10$ neurons; $b p V(H), n=29$ neurons). Data are mean \pm SEM. ${ }^{* * *} p<0.001$ (two-sided $t$ test vs Control). E, Mice were injected subcutaneously with saline as a control or the PTEN inhibitor bpV(Phen) $(3 \mathrm{mg} / \mathrm{kg})$. TG neurons were isolated 2, 4, and $6 \mathrm{~h}$ after injection. Representative images are shown for cells labeled live with Hoechst DNA stain (blue) and Deltorphin II-Cy3 (red). Scale bars, $15 \mu \mathrm{m}$. F, Quantitation shows a significant increase in the fraction of delt-Cy3-positive cells 4 and $6 \mathrm{~h}$ after PTEN inhibition (contingency plot is shown; saline, $n=234$ neurons; bpV(H) $2 \mathrm{~h}, n=94$ neurons; bpV(H) $4 \mathrm{~h}, n=132$ neurons; bpV(H) $6 \mathrm{~h}, n=147$ neurons). $*^{* * *} p<0.0001$. n.s., Not significant ( $p>0.05$, by Fisher Exact test vs saline).

\section{PTEN inhibition stimulates surface delivery of endogenous $\delta \mathrm{R}$ in TG neurons in vivo}

We next tested whether PTEN inhibition drives endogenous $\delta \mathrm{R}$ to the surface of TG neurons in vivo. Because the lack of specific antibodies made the detection of endogenous $\delta \mathrm{R}$ challenging, we conjugated the fluorophore $\mathrm{Cy}-3$ to the $\mathrm{C}$ terminus of the $\delta \mathrm{R}$ specific agonist Deltorphin II (delt-Cy3) (Fig. 5A). This approach has been used to detect endogenous GPCRs previously (Arttamangkul et al., 2000), and our conjugation strategy preserved the binding interface of Deltorphin II to $\delta \mathrm{R}$. To test whether PTEN inhibition released the intracellular retention of endogenous $\delta \mathrm{R}$ in TG neurons, TG neurons were incubated with delt-Cy3 for 10 min following $60 \mathrm{~min}$ of PTEN inhibition or control. The cells were then imaged live via confocal microscopy to quantify the amount of fluorescent delt-Cy3 labeling, as an index of the amount of $\delta \mathrm{R}$ present on the cell surface. Neurons positive for delt-Cy3 showed endosome staining due to receptor internalization (Fig. 5B). For neurons that were treated with the PTEN inhibitor bpV(Phen), the integrated density of delt-Cy3 fluorescence per cell was significantly higher compared with control treated neurons (Fig. 5C). Additionally, the number of endosomes observed per neuron also increased significantly following PTEN inhibition, consistent with increased surface binding and internalization of delt-Cy3. Together, this suggests that PTEN inhibition increases the surface levels of endogenous $\delta \mathrm{R}$ in TG neurons.

To determine whether PTEN inhibition would increase the pool of endogenous $\delta \mathrm{R}$ in vivo, we injected adult mice subcutaneously with the PTEN inhibitor bpV(Phen), or saline as a control, isolated TG neurons 2, 4, or $6 \mathrm{~h}$ after injection, and labeled them live with delt-Cy3 to detect surface $\delta \mathrm{R}$ by confocal imaging. The cells were counterstained with Hoechst DNA stain to assess the fraction of TG neurons labeled by delt-Cy3. In saline-injected mice, only a small fraction $(\sim 14 \%)$ of neurons were labeled with delt-Cy3 (Fig. $5 E, F)$. The fraction $(\sim 21 \%)$ was approximately comparable (not significant by Fisher's Exact test) after $2 \mathrm{~h}$ of PTEN inhibition. In contrast, 
A

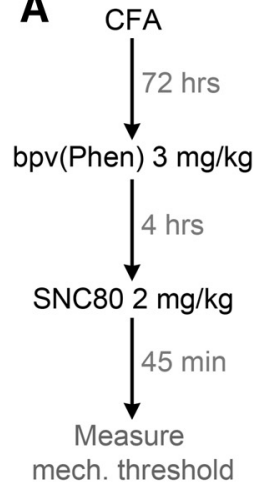

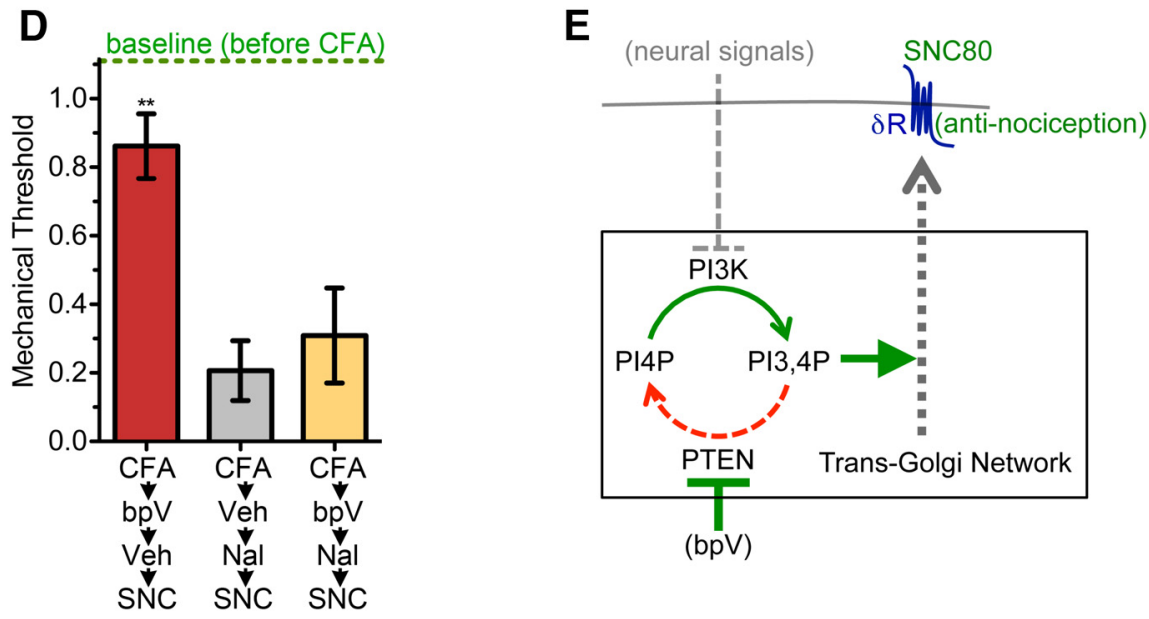

Figure 6. PTEN inhibition unmasks the antihyperalgesic efficacy of the $\delta$ R agonist SNC80. $\boldsymbol{A}$, The threshold for mechanical hyperalgesia was determined using a manual von Frey hair, in mice after intraplantar injection of CFA. A schematic shows the timeline and doses used in our experiments. $\boldsymbol{B}$, Mechanical thresholds in mice show that pretreatment with PTEN inhibitor unmasked the antihyperalgesic effects of SNC80 (mean \pm SEM). ${ }^{* *} p<0.01$. SNC80 or bpv (Phen) on their own did not show antihyperalgesia compared with control vehicle-injected mice. The mechanical threshold before CFA treatment was used as baseline (green dashed line). C, A schematic showing the timeline and doses used in testing whether naltrindole blocks the bpV(Phen)-mediated increase in SNC80 efficacy. $\boldsymbol{D}$, Naltrindole abolishes the increase in SNC80-mediated antihyperalgesia caused by PTEN inhibition (mean \pm SEM). ${ }^{* *} p<0.01$. E, Proposed model for how PTEN/PI3K balance provides a Golgi checkpoint to regulate $\delta R$ export and surface availability. Following neuronal signals, such as NGF, $\delta R$ is retained within the TGN due to disruption of the $3^{\prime}$ phosphoinositide balance by either inhibiting PI3K or increasing PTEN activity. By blocking PTEN activity via pharmacologic inhibition, $3^{\prime}$ phosphorylation of phosphoinositides is maintained and $\delta R$ surface trafficking is stimulated. Increased $\delta R$ surface trafficking via PTEN inhibition results in greater receptor surface localization, increased agonist-induced $\delta R$ function, and unmasks the antihyperalgesic effects of SNC80.

after 4 h of PTEN inhibition, $\sim 80 \%$ of neurons were labeled with delt-Cy3 $(p<0.0001)$. This increase persisted after $6 \mathrm{~h}$, although the fraction $(\sim 48 \%)$ was lower than that observed at $4 \mathrm{~h}$ (Fig. $5 E, F)$. These data show that PTEN inhibition drives a functional pool of $\delta \mathrm{R}$ to the surface of TG neurons and that the maximal effect was observed $4 \mathrm{~h}$ after PTEN inhibition in vivo.

\section{Stimulated $\delta \mathrm{R}$ delivery unmasks antihyperalgesic efficacy of SNC80 in mice}

Because $\delta \mathrm{R}$ is an attractive target for pain management, we next tested whether stimulated $\delta \mathrm{R}$ delivery increases receptor availability enough to increase the efficacy of $\delta \mathrm{R}$ agonists. We chose the complete Freund's adjuvant (CFA) model of chronic inflammatory pain in mice because it is a well-accepted and commonly used paradigm for chronic pain and one in which $\delta \mathrm{R}$ agonists have shown partial effects at high doses. In addition, previous

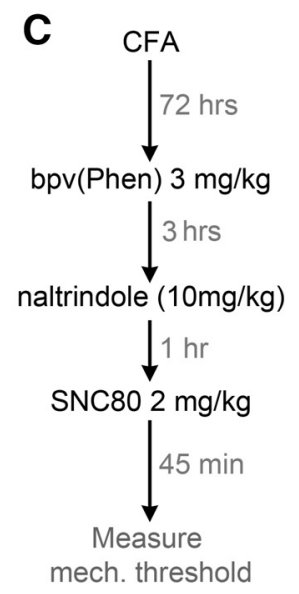

mech. threshold studies using conditional knock-out mice have shown that $\delta \mathrm{R}$-expressing neurons in peripheral ganglia are critical for the pain-relieving effects of the $\delta \mathrm{R}$ agonist $\mathrm{SNC80}$ within the CFA model (Gavériaux-Ruff and Kieffer, 2011). To test antihyperalgesia, mice were injected with CFA in the left hindpaw, and the experiments were performed $72 \mathrm{~h}$ later. Mechanical threshold analysis was performed using von Frey filaments 45 min after the final treatment condition, as described previously (Fig. 6A) (Pradhan et al., 2013). We first tested multiple doses of the PTEN inhibitor $\mathrm{bpV}$ (Phen) pretreatment to evaluate whether PTEN inhibition on its own altered the CFA-induced mechanical hyperalgesia. A PTEN inhibitor concentration of $3 \mathrm{mg} / \mathrm{kg}$ (s.c.) did not alter the CFA-induced mechanical hyperalgesia, and was chosen as an appropriate dose for further studies. In CFA-injected mice, neither $\mathrm{bpv}(\mathrm{Phen})$ alone nor the dose of SNC80 tested (2 mg/kg i.p.) relieved CFAinduced mechanical hyperalgesia (Fig. $6 B$ ). Our previous experiments in naive mice suggested that $\mathrm{bpv}(\mathrm{Phen})$ would be most effective at potentiating SNC80 $4 \mathrm{~h}$ after administration. Preadministration of $\operatorname{bpv}($ Phen) $4 \mathrm{~h}$ before testing significantly increased the efficacy of this dose of SNC80 (Fig. 6B). Importantly, in these conditions, robust antihyperalgesia was observed without noticeable adverse effects, such as convulsions.

To confirm that the antihyperalgesic effect induced by PTEN inhibition was caused by increased activation of $\delta \mathrm{R}$, we tested whether naltrindole, a $\delta \mathrm{R}$-selective antagonist, could block the effect of SNC80 in these conditions. We followed a similar paradigm as in Figure $6 A$, with an additional injection of vehicle or naltrindole $(10 \mathrm{mg} / \mathrm{kg}) 1 \mathrm{~h}$ before SNC80 (Fig. 6C). bpV(Phen)-treated animals injected with vehicle before SNC80 showed a significantly increased antihyperalgesic response, comparable with what was seen in Figure 6B. Strikingly, the SNC80-induced antihyperalgesia caused by bpV(Phen) was completely abolished by naltrindole, indicating that this antihyperalgesia was likely $\delta \mathrm{R}$ mediated (Fig. 6D). Animals treated with naltrindole, without bpV(Phen), also did not show antihyperalgesia with SNC80. Together, our data support the physiological relevance of our model that PTEN inhibition bypasses a critical Golgi export checkpoint to drive the intracellular pool of $\delta \mathrm{R}$ to the neuronal surface and increase the efficacy of $\delta \mathrm{R}$ agonists (Fig. $6 E$ ).

\section{Discussion}

It is well established that controlling the number of surface receptors, by removal or delivery, is a critical method to control the potency and efficacy of signals. Our understanding of this process has largely been limited to studies of receptor endocytosis and 
recycling, where many mechanisms and pathways of regulation have been described (Sorkin and Zastrow, 2002; Marchese and Trejo, 2013). The current results, by identifying PTEN as an important factor that controls the delivery of newly synthesized $\delta \mathrm{R}$, show that regulated delivery from the biosynthetic pathway can control $\delta \mathrm{R}$ physiology.

Intracellular retention of $\delta \mathrm{R}$ has been reported in a variety of neurons, but the details vary depending on the systems tested (Zhang et al., 1998; Cahill et al., 2001b; Bao et al., 2003; Kim and von Zastrow, 2003; Walwyn et al., 2005; Cahill et al., 2007; Mittal et al., 2013; Gendron et al., 2015). In DRG neurons and induced chromaffin cells, $\delta \mathrm{R}$ is localized to large dense-core vesicles (Guan et al., 2005; Wang et al., 2010). In PC12 cells and hippocampal neurons, $\delta \mathrm{R}$ is localized to the Golgi (Kim and von Zastrow, 2003), similar to what we report in this study. It is possible that these differences reflect cell-type-dependent differences in receptor behavior. The intracellular localization is reduced upon tagging the receptors on the C-terminal tail with GFP (Scherrer et al., 2009; Wang et al., 2010) but is retained in HA and Myc-tagged $\delta$ Rs in small-diameter DRG neurons (Wang et al., 2008, 2010; Zhang et al., 2015). This differential subcellular localization seen with different tags suggests that intracellular retention of $\delta \mathrm{R}$ is an actively regulated process, dependent on sequences along the cytoplasmic surface of the receptor, which is shared across multiple neuronal types.

Nevertheless, the regulation of Golgi export of $\delta \mathrm{R}$ might be diverse and neuron-specific. In mature neurons, $\delta \mathrm{R}$ is localized primarily to intracellular structures even without extraneous NGF signaling (Fig. 1A) (Zhang et al., 1998; Cahill et al., 2001b; Bao et al., 2003; Kim and von Zastrow, 2003; Walwyn et al., 2005; Cahill et al., 2007; Gendron et al., 2015). This suggests that neuronal differentiation causes persistent changes in cellular signaling that maintain the regulated receptor trafficking through this Golgi checkpoint. In brainstem slices, however, chronic NGF treatment of $>4$ h increased the deltorphin-dependent suppression of EPSCs (Bie et al., 2010). It is possible that NGF elicits different functional responses in central neurons compared with peripheral neurons, as the increased response was prevented by a PI3K inhibitor (Bie et al., 2010). At these timescales, however, NGF might also increase expression of many genes, including $\delta$, via transcriptional and epigenetic changes (Huang and Reichardt, 2003; Chen et al., 2008), and it is conceivable that the total response could increase, even though the majority of receptors are retained in intracellular pools. Consistent with this, NGF and neuronal differentiation, via a complex of proteins associated with ARMS/Kidins220, can increase the surface pools of glutamate receptors and secreted cargo, such as the human growth hormone (Arévalo et al., 2010; López-Benito et al., 2016). Conditions, such as chronic inflammation, or pharmacological chaperones, which increase total $\delta \mathrm{R}$ mRNA and protein expression, are also associated with a proportional increase in surface $\delta \mathrm{R}$, which could enhance the potency of $\delta$ R agonists (Bao et al., 2003; Cahill et al., 2003; Kim and von Zastrow, 2003; Patwardhan et al., 2005; Cahill et al., 2007; Pettinger et al., 2013). Inflammation-induced priming of neurons to $\delta \mathrm{R}$ also involves a GRK2-RIPK-mediated modulation of $\delta \mathrm{R}$ function, presumably independent of trafficking (Brackley et al., 2016). It is possible that $\delta \mathrm{R}$ function is modulated by both regulated trafficking to the cell surface as well as a separate priming step at the cell surface, using overlapping mechanisms.

The physiological necessity of intracellular $\delta \mathrm{R}$ retention in neurons, however, is not well understood. A key difference between $\delta \mathrm{R}$ and $\mu \mathrm{R}$ is that $\delta \mathrm{R}$ is internalized and largely degraded after activation by many ligands, whereas $\mu \mathrm{R}$ is largely recycled and reused. Neurons rely on the delivery of newly synthesized $\delta \mathrm{R}$ for recovery of signaling. The intracellular $\delta \mathrm{R}$ could therefore be a "reserve" pool that can be readily delivered to the surface, on demand, much faster than if the receptor had to be synthesized $d e$ novo after internalization and degradation of existing surface $\delta \mathrm{R}$. Consistent with this, $\delta \mathrm{R}$ activation itself might serve as a cue for increasing $\delta \mathrm{R}$ responses, through ROCK-LIMK-mediated changes in the actin cytoskeleton, which regulates agonist-dependent coupling of $\delta \mathrm{R}$ to voltage-dependent calcium channels (Mittal et al., 2013). In our hands, the ROCK pathway was not involved in NGF- or PTEN-regulated $\delta$ R transport in the absence of agonists, suggesting that the PI3K/PTEN-mediated release and agonistinduced release play distinct roles in $\delta \mathrm{R}$ function on the cell surface.

In addition to serving as a reserve pool, $\delta \mathrm{R}$ in the Golgi could serve an as-yet undiscovered signaling function. Recent data suggest that signals from the related catecholamine receptor, the $\beta 2$-adrenergic receptor, are spatially encoded, with the same downstream second messengers at different cellular locations activating distinct subsets of genes (Tsvetanova and Zastrow, 2014; Bowman et al., 2016). It is conceivable that the Golgi pool of $\delta \mathrm{R}$ serves a similar function by spatially separating signals originating from the cell surface and the Golgi. Attempts to activate intracellular $\delta \mathrm{R}$ using agonists that are membrane permeable, however, have been largely unsuccessful. Therefore, while the intracellular $\delta \mathrm{R}$ might be competent for signaling, it is not sufficient to cause analgesia, and the analgesic response requires surface localization of $\delta \mathrm{R}$. In this context, the signaling-regulated checkpoint for TGN export of $\delta \mathrm{R}$ export at the TGN, which we identify here, provides a target to independently manipulate surface delivery of $\delta \mathrm{R}$ and increase antihyperalgesic responses to $\delta \mathrm{R}$ agonists.

Our results provide an important proof of concept: that independently manipulating trafficking of $\delta \mathrm{R}$ is a viable strategy to improve the bioavailability of $\delta \mathrm{R}$ on the surface and to increase the efficacy of $\delta \mathrm{R}$ agonists. Previous attempts at targeting $\delta \mathrm{R}$ to manage pain have mainly focused on developing better $\delta \mathrm{R}$ agonists (Scherrer et al., 2009; Gavériaux-Ruff and Kieffer, 2011; Bardoni et al., 2014). However, these efforts have largely been unsuccessful, as available agonists show poor in vivo efficacy, necessitating the use of high doses that cause adverse effects. Our study provides a critical example on which to base future strategies to improve the bioavailability of $\delta \mathrm{R}$ and increase the responsiveness of neurons to the many $\delta \mathrm{R}$ agonists already developed. Engineered relocation of receptors may therefore provide a general blueprint to precisely manipulate the physiology of many GPCRs that are localized to intracellular pools.

\section{References}

Arévalo JC, Wu SH, Takahashi T, Zhang H, Yu T, Yano H, Milner TA, Tessarollo L, Ninan I, Arancio O, Chao MV (2010) The ARMS/Kidins220 scaffold protein modulates synaptic transmission. Mol Cell Neurosci 45: 92-100. CrossRef Medline

Arttamangkul S, Alvarez-Maubecin V, Thomas G, Williams JT, Grandy DK (2000) Binding and internalization of fluorescent opioid peptide conjugates in living cells. Mol Pharmacol 58:1570-1580. CrossRef Medline

Arttamangkul S, Quillinan N, Low MJ, von Zastrow M, Pintar J, Williams JT (2008) Differential activation and trafficking of micro-opioid receptors in brain slices. Mol Pharmacol 74:972-979. CrossRef Medline

Balla T, Wymann M, York JD (2012) Phosphoinositides I: Enzymes of synthesis and degradation. New York: Springer.

Bao L, Jin SX, Zhang C, Wang LH, Xu ZZ, Zhang FX, Wang LC, Ning FS, Cai HJ, Guan JS, Xiao HS, Xu ZQ, He C, Hökfelt T, Zhou Z, Zhang X (2003) Activation of $\delta$ opioid receptors induces receptor insertion and neuropeptide secretion. Neuron 37:121-133. CrossRef Medline 
Bardoni R, Tawfik VL, Wang D, François A, Solorzano C, Shuster SA, Choudhury P, Betelli C, Cassidy C, Smith K, de Nooij JC, Mennicken F, O’Donnell D, Kieffer BL, Woodbury CJ, Basbaum AI, MacDermott AB, Scherrer G (2014) Delta opioid receptors presynaptically regulate cutaneous mechanosensory neuron input to the spinal cord dorsal horn. Neuron 81:1312-1327. CrossRef Medline

Bie B, Zhang Z, Cai YQ, Zhu W, Zhang Y, Dai J, Lowenstein CJ, Weinman EJ, Pan ZZ (2010) Nerve growth factor-regulated emergence of functional $\delta$-opioid receptors. J Neurosci 30:5617-5628. CrossRef Medline

Bowman SL, Soohoo AL, Shiwarski DJ, Schulz S, Pradhan AA, Puthenveedu MA (2015) Cell-autonomous regulation of Mu-opioid receptor recycling by substance P. Cell Rep 10:1925-1936. CrossRef Medline

Bowman SL, Shiwarski DJ, Puthenveedu MA (2016) Distinct G proteincoupled receptor recycling pathways allow spatial control of downstream G protein signaling. J Cell Biol 214:797-806. CrossRef Medline

Brackley AD, Gomez R, Akopian AN, Henry MA, Jeske NA (2016) GRK2 constitutively governs peripheral delta opioid receptor activity. Cell Rep 16:2686-2698. CrossRef Medline

Cahill CM, McClellan KA, Morinville A, Hoffert C, Hubatsch D, O’Donnell D, Beaudet A (2001a) Immunohistochemical distribution of $\delta$ opioid receptors in the rat central nervous system: evidence for somatodendritic labeling and antigen-specific cellular compartmentalization. J Comp Neurol 440:65-84. CrossRef Medline

Cahill CM, Morinville A, Lee MC, Vincent JP, Collier B, Beaudet A (2001b) Prolonged morphine treatment targets $\delta$ opioid receptors to neuronal plasma membranes and enhances $\delta$-mediated antinociception. J Neurosci 21:7598-7607. Medline

Cahill CM, Morinville A, Hoffert C, O’Donnell D, Beaudet A (2003) Upregulation and trafficking of $\delta$ opioid receptor in a model of chronic inflammation: implications for pain control. Pain 101:199-208. CrossRef Medline

Cahill CM, Holdridge SV, Morinville A (2007) Trafficking of $\delta$-opioid receptors and other G-protein-coupled receptors: implications for pain and analgesia. Trends Pharmacol Sci 28:23-31. CrossRef Medline

Chen JY, Lin JR, Cimprich KA, Meyer T (2012) A two-dimensional ERKAKT signaling code for an NGF-triggered cell-fate decision. Mol Cell 45:196-209. CrossRef Medline

Chen YL, Law PY, Loh HH (2008) NGF/PI3K signaling-mediated epigenetic regulation of $\delta$ opioid receptor gene expression. Biochem Biophys Res Commun 368:755-760. CrossRef Medline

Cheng PY, Liu-Chen LY, Pickel VM (1997) Dual ultrastructural immunocytochemical labeling of mu and $\delta$ opioid receptors in the superficial layers of the rat cervical spinal cord. Brain Res 778:367-380. CrossRef Medline

Christie KJ, Webber CA, Martinez JA, Singh B, Zochodne DW (2010) PTEN inhibition to facilitate intrinsic regenerative outgrowth of adult peripheral axons. J Neurosci 30:9306-9315. CrossRef Medline

Danielsson I, Gasior M, Stevenson GW, Folk JE, Rice KC, Negus SS (2006) Electroencephalographic and convulsant effects of the $\delta$ opioid agonist SNC80 in rhesus monkeys. Pharmacol Biochem Behav 85:428-434. CrossRef Medline

De Matteis MA, Godi A (2004) PI-loting membrane traffic. J Cell Biol 6:487-492. CrossRef Medline

de Rooij J, Zwartkruis FJ, Verheijen MH, Cool RH, Nijman SM, Wittinghofer A, Bos JL (1998) Epac is a Rap1 guanine-nucleotide-exchange factor directly activated by cyclic AMP. Nature 396:474-477. Medline

DiPilato LM, Cheng X, Zhang J (2004) Fluorescent indicators of cAMP and Epac activation reveal differential dynamics of cAMP signaling within discrete subcellular compartments. Proc Natl Acad Sci U S A 101:1651316518. CrossRef Medline

Gavériaux-Ruff C, Kieffer BL (2011) Delta opioid receptor analgesia: recent contributions from pharmacology and molecular approaches. Behav Pharmacol 22:405-414. CrossRef Medline

Gavériaux-Ruff C, Karchewski LA, Hever X, Matifas A, Kieffer BL (2008) Inflammatory pain is enhanced in $\delta$ opioid receptor-knockout mice. Eur J Neurosci 27:2558-2567. CrossRef Medline

Gendron L, Mittal N, Beaudry H, Walwyn W (2015) Recent advances on the $\delta$ opioid receptor: from trafficking to function. Br J Pharmacol 172:403419. CrossRef Medline

Gendron L, Cahill CM, von Zastrow M, Schiller PW, Piñeyro G (2016) Molecular pharmacology of $\delta$-opioid receptors. Pharmacol Rev 68:631-700. CrossRef Medline
Guan JS, Xu ZZ, Gao H, He SQ, Ma GQ, Sun T, Wang LH, Zhang ZN, Lena I, Kitchen I, Elde R, Zimmer A, He C, Pei G, Bao L, Zhang X (2005) Interaction with vesicle luminal protachykinin regulates surface expression of $\delta$-opioid receptors and opioid analgesia. Cell 122:619-631. CrossRef Medline

Guan XM, Kobilka TS, Kobilka BK (1992) Enhancement of membrane insertion and function in a type IIIb membrane protein following introduction of a cleavable signal peptide. J Biol Chem 267:21995-21998. Medline

Gupta A, Gomes I, Wardman J, Devi LA (2014) Opioid receptor function is regulated by post-endocytic peptide processing. J Biol Chem 289:1961319626. CrossRef Medline

Harriott AM, Scheff NN, Gold MS (2012) The complex actions of sumatriptan on rat dural afferents. Cephalalgia 32:738-749. CrossRef Medline

Huang EJ, Reichardt LF (2003) Trk receptors: roles in neuronal signal transduction. Annu Rev Biochem 72:609-642. CrossRef Medline

Jutkiewicz EM, Baladi MG, Folk JE, Rice KC, Woods JH (2006) The convulsive and electroencephalographic changes produced by nonpeptidic $\delta$-opioid agonists in rats: comparison with pentylenetetrazol. J Pharmacol Exp Ther 317:1337-1348. CrossRef Medline

Kim KA, von Zastrow M (2003) Neurotrophin-regulated sorting of opioid receptors in the biosynthetic pathway of neurosecretory cells. J Neurosci 23:2075-2085. Medline

Lachyankar MB, Sultana N, Schonhoff CM, Mitra P, Poluha W, Lambert S, Quesenberry PJ, Litofsky NS, Recht LD, Nabi R, Miller SJ, Ohta S, Neel BG, Ross AH (2000) A role for nuclear PTEN in neuronal differentiation. J Neurosci 20:1404-1413. Medline

Liu K, Lu Y, Lee JK, Samara R, Willenberg R, Sears-Kraxberger I, Tedeschi A, Park KK, Jin D, Cai B, Xu B, Connolly L, Steward O, Zheng B, He Z (2010) PTEN deletion enhances the regenerative ability of adult corticospinal neurons. Nat Neurosci 13:1075-1081. CrossRef Medline

López-Benito S, Lillo C, Hernández-Hernández Á, Chao MV, Arévalo JC (2016) ARMS/Kidins220 and synembryn-B levels regulate NGF-mediated secretion. J Cell Sci 129:1866-1877. CrossRef Medline

Lu SG, Zhang X, Gold MS (2006) Intracellular calcium regulation among subpopulations of rat dorsal root ganglion neurons. J Physiol 577:169190. CrossRef Medline

Marchese A, Trejo J (2013) Ubiquitin-dependent regulation of G proteincoupled receptor trafficking and signaling. Cell Signal 25:707-716. CrossRef Medline

Mittal N, Roberts K, Pal K, Bentolila LA, Fultz E, Minasyan A, Cahill C, Pradhan A, Conner D, DeFea K, Evans C, Walwyn W (2013) Select G-protein-coupled receptors modulate agonist-induced signaling via a ROCK, LIMK, and $\beta$-arrestin 1 pathway. Cell Rep 5:1010-1021. CrossRef Medline

Patwardhan AM, Berg KA, Akopain AN, Jeske NA, Gamper N, Clarke WP, Hargreaves KM (2005) Bradykinin-induced functional competence and trafficking of the $\delta$-opioid receptor in trigeminal nociceptors. J Neurosci 25:8825-8832. CrossRef Medline

Patwardhan AM, Diogenes A, Berg KA, Fehrenbacher JC, Clarke WP, Akopian AN, Hargreaves KM (2006) PAR-2 agonists activate trigeminal nociceptors and induce functional competence in the $\delta$ opioid receptor. Pain 125:114-124. CrossRef Medline

Petaja-Repo UE, Hogue M, Laperriere A, Walker P, Bouvier M (2000) Export from the endoplasmic reticulum represents the limiting step in the maturation and cell surface expression of the human $\delta$ opioid receptor. J Biol Chem 275:13727-13736. CrossRef Medline

Pettinger L, Gigout S, Linley JE, Gamper N (2013) Bradykinin controls pool size of sensory neurons expressing functional $\delta$-opioid receptors. J Neurosci 33:10762-10771. CrossRef Medline

Ponsioen B, Zhao J, Riedl J, Zwartkruis F, van der Krogt G, Zaccolo M, Moolenaar WH, Bos JL, Jalink K (2004) Detecting cAMP-induced Epac activation by fluorescence resonance energy transfer: Epac as a novel cAMP indicator. EMBO Rep 5:1176-1180. CrossRef Medline

Pradhan AA, Befort K, Nozaki C, Gavériaux-RuffC, Kieffer BL (2011) The $\delta$ opioid receptor: an evolving target for the treatment of brain disorders. Trends Pharmacol Sci 32:581-590. CrossRef Medline

Pradhan A, Smith M, McGuire B, Evans C, Walwyn W (2013) Chronic inflammatory injury results in increased coupling of $\delta$ opioid receptors to voltage-gated $\mathrm{Ca}^{2+}$ channels. Mol Pain 9:8. CrossRef Medline

Puthenveedu MA, Lauffer B, Temkin P, Vistein R, Carlton P, Thorn K, Taunton J, Weiner OD, Parton RG, von Zastrow M (2010) Sequence- 
dependent sorting of recycling proteins by actin-stabilized endosomal microdomains. Cell 143:761-773. CrossRef Medline

Ross AH, Lachyankar MB, Recht LD (2001) PTEN: a newly identified regulator of neuronal differentiation. Neuroscientist 7:278-281. CrossRef Medline

Rowan MP, Ruparel NB, Patwardhan AM, Berg KA, Clarke WP, Hargreaves KM (2009) Peripheral $\delta$ opioid receptors require priming for functional competence in vivo. Eur J Pharmacol 602:283-287. CrossRef Medline

Scherrer G, Imamachi N, Cao YQ, Contet C, Mennicken F, O’Donnell D, Kieffer BL, Basbaum AI (2009) Dissociation of the opioid receptor mechanisms that control mechanical and heat pain. Cell 137:1148-1159. CrossRef Medline

Sneddon WB, Magyar CE, Willick GE, Syme CA, Galbiati F, Bisello A, Friedman PA (2004) Ligand-selective dissociation of activation and internalization of the parathyroid hormone (PTH) receptor: conditional efficacy of PTH peptide fragments. Endocrinology 145:2815-2823. CrossRef Medline

Song MS, Salmena L, Pandolfi PP (2012) The functions and regulation of the PTEN tumour suppressor. Nat Rev Mol Cell Biol 13:283-296. CrossRef Medline

Soohoo AL, Puthenveedu MA (2013) Divergent modes for cargo-mediated control of clathrin-coated pit dynamics. Mol Biol Cell 24:1725-1734; S1S12. CrossRef Medline

Sorkin A, von Zastrow M (2002) Signal transduction and endocytosis: close encounters of many kinds. Nat Rev Mol Cell Biol 3:600-614. CrossRef Medline

Stein C, Millan MJ, Shippenberg TS, Peter K, Herz A (1989) Peripheral opioid receptors mediating antinociception in inflammation: evidence for involvement of mu, delta and kappa receptors. J Pharmacol Exp Ther 248:1269-1275. Medline

Svingos AL, Cheng PY, Clarke CL, Pickel VM (1995) Ultrastructural localization of $\delta$-opioid receptor and Met5-enkephalin immunoreactivity in rat insular cortex. Brain Res 700:25-39. CrossRef Medline
Tsvetanova NG, von Zastrow M (2014) Spatial encoding of cyclic AMP signaling specificity by GPCR endocytosis. Nat Chem Biol 10:1061-1065. CrossRef Medline

Vanderah TW (2010) Delta and kappa opioid receptors as suitable drug targets for pain. Clin J Pain 26 [Suppl 10]:S10-S15.

Vaughn AH, Gold MS (2010) Ionic mechanisms underlying inflammatory mediator-induced sensitization of dural afferents. J Neurosci 30:7878 7888. CrossRef Medline

Vistein R, Puthenveedu MA (2013) Reprogramming of G protein-coupled receptor recycling and signaling by a kinase switch. Proc Natl Acad Sci U S A 110:15289-15294. CrossRef Medline

Walwyn W, Maidment NT, Sanders M, Evans CJ, Kieffer BL, Hales TG (2005) Induction of $\delta$ opioid receptor function by up-regulation of membrane receptors in mouse primary afferent neurons. Mol Pharmacol 68:1688-1698. CrossRef Medline

Wang H, Pickel VM (2001) Preferential cytoplasmic localization of $\delta$-opioid receptors in rat striatal patches: comparison with plasmalemmal mu-opioid receptors. J Neurosci 21:3242-3250. Medline

Wang HB, Guan JS, Bao L, Zhang X (2008) Distinct subcellular distribution of $\delta$-opioid receptor fused with various tags in PC12 cells. Neurochem Res 33:2028-2034. CrossRef Medline

Wang HB, Zhao B, Zhong YQ, Li KC, Li ZY, Wang Q, Lu YJ, Zhang ZN, He SQ, Zheng HC, Wu SX, Hökfelt TG, Bao L, Zhang X (2010) Coexpression of delta- and mu-opioid receptors in nociceptive sensory neurons. Proc Natl Acad Sci U S A 107:13117-13122. CrossRef Medline

Zhang X, Bao L, Arvidsson U, Elde R, Hökfelt T (1998) Localization and regulation of the $\delta$-opioid receptor in dorsal root ganglia and spinal cord of the rat and monkey: evidence for association with the membrane of large dense-core vesicles. Neuroscience 82:1225-1242. CrossRef Medline

Zhang X, Bao L, Li S (2015) Opioid receptor trafficking and interaction in nociceptors. Br J Pharmacol 172:364-374. CrossRef Medline 